\title{
Complex Formation of Glycosyltransferases and Their Biological Significance
}

\author{
糖転移酵素の複合体形成とその意義
}

\author{
Seko, Akira \\ Innovation Research Initiatives, Tokyo Institute of Technology, Nagatsuda 4259, Midori-ku, Yokohama, 226-8503, \\ and CREST, Japan Science and Technology Agency, 4-1-8 Honcho, Kawaguchi, Saitama, 332-0012, Japan \\ FAX: 81-45-921-4308, E-mail: aseko@ bio.titech.ac.jp \\ Key Words: glycosyltransferase, sulfotransferase, complex, oligomer, heteromer
}

\begin{abstract}
Recently, it has become clear that glycosyltransferases(GTs) form complexes in various manners. Some GTs can associate by themselves to form homodimers or homooligomers, while other GTs can associate with non-GT proteins to form hetero-oligomers. The biological significance of the complex formation is diverse; activation or stabilization of catalytic activities, alteration of substrate specificities, economical biosynthesis of glycans, localization and transport in the ER or the Golgi apparatus, modification of catalytic activities via certain effector proteins, and so on. Here, I will review a number of studies on GT complexes.
\end{abstract}

要 約

近年糖転移酵素が種々の様式で複合体を形成することが 判ってきた。ある種の糖転移酵素はホモダイマーやホモオリ ゴマーを形成し、またあるものは糖転移酵素以外の夕ンパク 質と会合し、へテロオリゴマーを形成する。糖転移酵素が複 合体を形成する生物学的意義として、酵素の触媒機能の安定 化や活性化、基質特異性の变化、効率的な糖鎖の合成、細胞 内オルガネラにおける局在性や輸送、他のエフェクタータン パク質による触媒機能の調節、などが挙げられる。このよう に糖転移酵素の複合体は機能的・構造的に多種多様であるが、 本稿ではこれら種々の研究例について概観する。

\section{A. 序 論}

糖転移酵素は、活性化された糖供与体から受容体基質へ 糖分子を転移する反応を司る酵素である。以前は糖転移酥素 が複合体を形成しているか否かについては、䤃素の精製に よって確かめる方法が主流で、その解析は困難であった。ま た糖鎖の生合成は各段階の糖転移酵素により逐次的に行なわ れるため、連続する反応を担う酵素群が相互作用しているこ とが推測されていた。実際 $2 、 3$ の先駆的研究によりそれが 明らかとなっていたが、多くのケースについては謎のままで あった。しかしながら近年様々な分析・分離技術が進歩し、 また酵母などに扔ける変異株の単離・解析により種々の糖転 移酵素が複合体を形成していることが明らかになった。そし てそれらの構成タンパク質の同定も進んでいる。最近の結果 では糖転移酵素は想像以上にゴルジ体や小胞体においてコン ビナトリアルに配置されており、効率良く糖鎖が生合成され ていることを支持している。

まずはホモ複合体についての報告例を表 I に、へテロ複合 体についての報告例を表 II にまとめた。ここで分類上注意し ていただきたいことがある。まず第一に、ゲルろ過や密度勾 配遠心によってモノマーの分子量より二倍以上大きな見かけ の分子量を示す分子群の存在が示された場合、表 I にホモ複合 体として取り扱ったが、これらはへテロ複合体の可能性を否 定するわけではないことである。そして第二に、免疫沈澱や タグを使った精製法により、二種の糖転移酵素もしくは糖転 移酵素と他の機能タンパク質とが会合していることが多く報 告されている。しかしこれらは分析対象の二つのタンパク質 
Table I. Homo-oligomerization of glycosyl- and sulfotransferases.

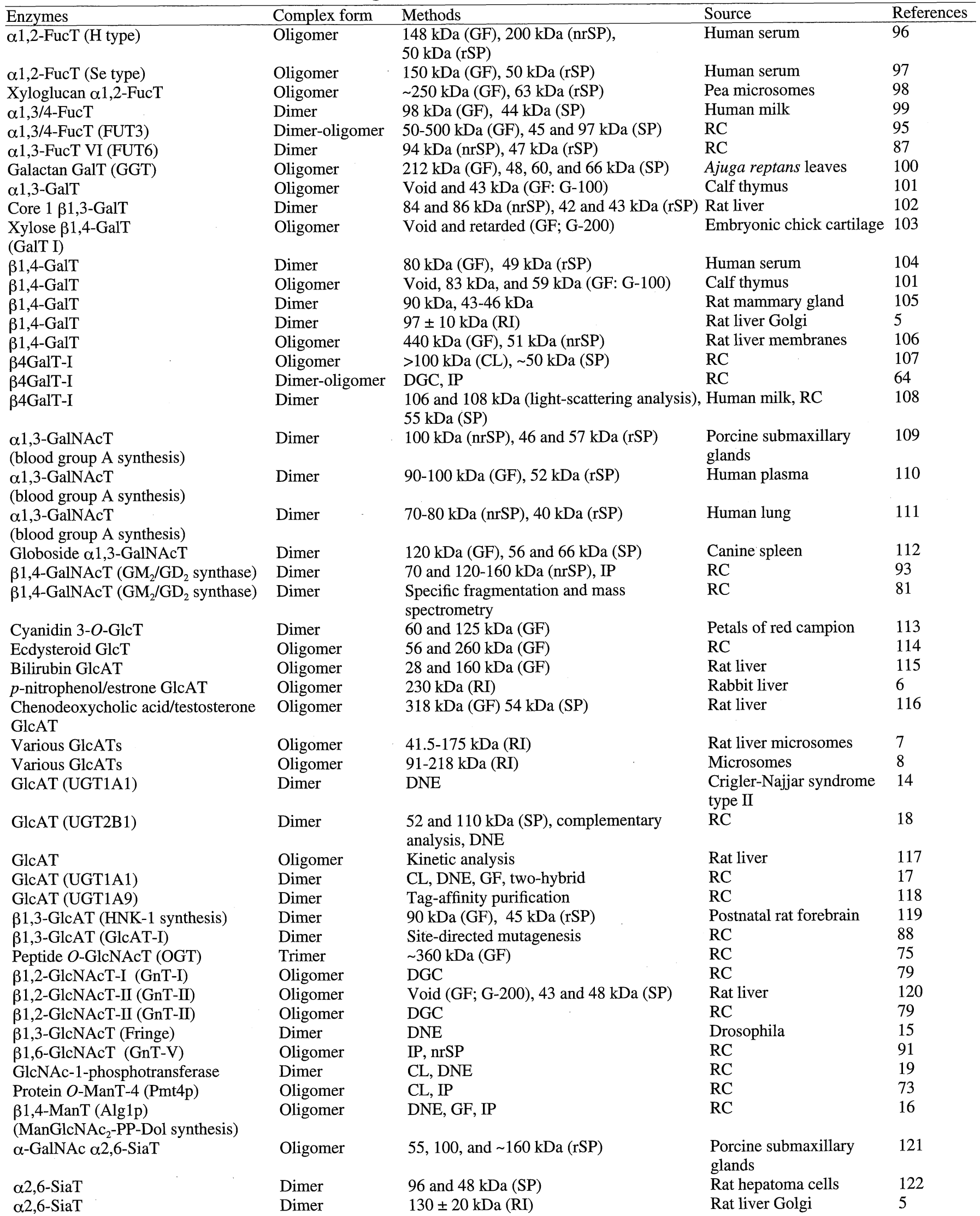




\begin{tabular}{|c|c|c|c|c|}
\hline $\alpha 2,6-$ SiaT (ST6Gal-I) & $\begin{array}{l}\text { Oligomer (STcys } \\
\text { isoform) Dimer } \\
\text { (STtyr isoform) }\end{array}$ & Detergent solubilization, SP & $\mathrm{RC}$, rat liver Golgi & Sum. in 1 \\
\hline$\alpha 2,8-\mathrm{SiaT}$ (ST8Sia-I, GD 3 synthase) & Dimer & $95 \mathrm{kDa}(\mathrm{nrSP}), 47 \mathrm{kDa}(\mathrm{rSP})$ & $\mathrm{RC}$ & 94 \\
\hline$\alpha 2,8-\mathrm{SiaT}$ (ST8Sia-I, GD 3 synthase) & Dimer & $170 \mathrm{kDa}(\mathrm{nrSP}), 85 \mathrm{kDa}(\mathrm{rSP})(\mathrm{GFP}$-fused) & $\mathrm{RC}$ & 31 \\
\hline Stachyose synthase (GalT) & Oligomer & 110 and $253 \mathrm{kDa}(\mathrm{GF}), \quad 90 \mathrm{kDa}(\mathrm{SP})$ & Adzuki bean & 123 \\
\hline Heparan sulfate $2-O$-SulT (HS2ST) & Oligomer & $130 \mathrm{kDa}(\mathrm{GF}), 44$ and $47 \mathrm{kDa}(\mathrm{rSP})$ & $\mathrm{CHO}$ cells & 124 \\
\hline Trehalose 2-O-SulT & Dimer & DGC & $\begin{array}{l}\text { Mycobacterium } \\
\text { tuberculosis }\end{array}$ & 80 \\
\hline Chondroitin 6-O-SulT (C6ST) & Dimer & $160 \mathrm{kDa}(\mathrm{GF}), 75 \mathrm{kDa}(\mathrm{rSP})$ & $\begin{array}{l}\text { Chick embryo } \\
\text { chondrocytes }\end{array}$ & 125 \\
\hline Chondroitin/keratan sulfate 6-O-SulT & Dimer & $150 \mathrm{kDa}(\mathrm{GF}), 75 \mathrm{kDa}(\mathrm{SP})$ & Chicken serum & 126 \\
\hline Gal 6-O-SulT & Dimer & $80-90$ and $170 \mathrm{kDa}(\mathrm{rSP})$ & Porcine lymph nodes & 127 \\
\hline Gal 6-O-SulT & Oligomer & Void (GF; S-300), 80 kDa (rSP) & Porcine serum & 128 \\
\hline GlcNAc 6-O-SulT (GlcNAc6ST-1) & Dimer & $150-160 \mathrm{kDa}(\mathrm{nrSP}), 85-90 \mathrm{kDa}(\mathrm{rSP})$ & $\mathrm{RC}$ & 89 \\
\hline $\begin{array}{l}\text { GlcNAc 6-O-SulT } \\
\text { (GlcNAc6ST-4, GST5) }\end{array}$ & Dimer & 50 and $\sim 100 \mathrm{kDa}(\mathrm{SP})$ & $\mathrm{RC}$ & 129 \\
\hline Heparan sulfate $6-O$-SulTs & Oligomer & $30-60$ and $>200 \mathrm{kDa}(\mathrm{GF})$ & $\mathrm{RC}$ & 90 \\
\hline
\end{tabular}

(HS6ST-1, -2, and -3)

CL, analysis with cross-linking reagents; DGC, density-gradient centrifugation; DNE, dominant negative effect; FucT, fucosyltransferase; GalT, galactosyltransferase; GalNAcT, $N$-acetylgalactosaminyltransferase; GlcT, glucosyltransferase; GlcAT, glucuronosyltransferase; GlcNAcT, $N$-acetylglucosaminyltransferase; GF, gel filtration; IP, immunoprecipitation using with antibodies against enzymes or tag-peptides; ManT, mannosyltransferase; nrSP, SDS-PAGE in non-reducing condition; PP-Dol, dolichol diphosphate; RC, recombinant proteins with/ without tag sequences; RI, radiation inactivation method; rSP, SDS-PAGE in reducing condition; SiaT, sialyltransferase; SP, SDS-PAGE; SulT, sulfotransferase.

Table II. Hetero-complex formation of glycosyl- and sulfotransferases with other transferases or non-transferase proteins.

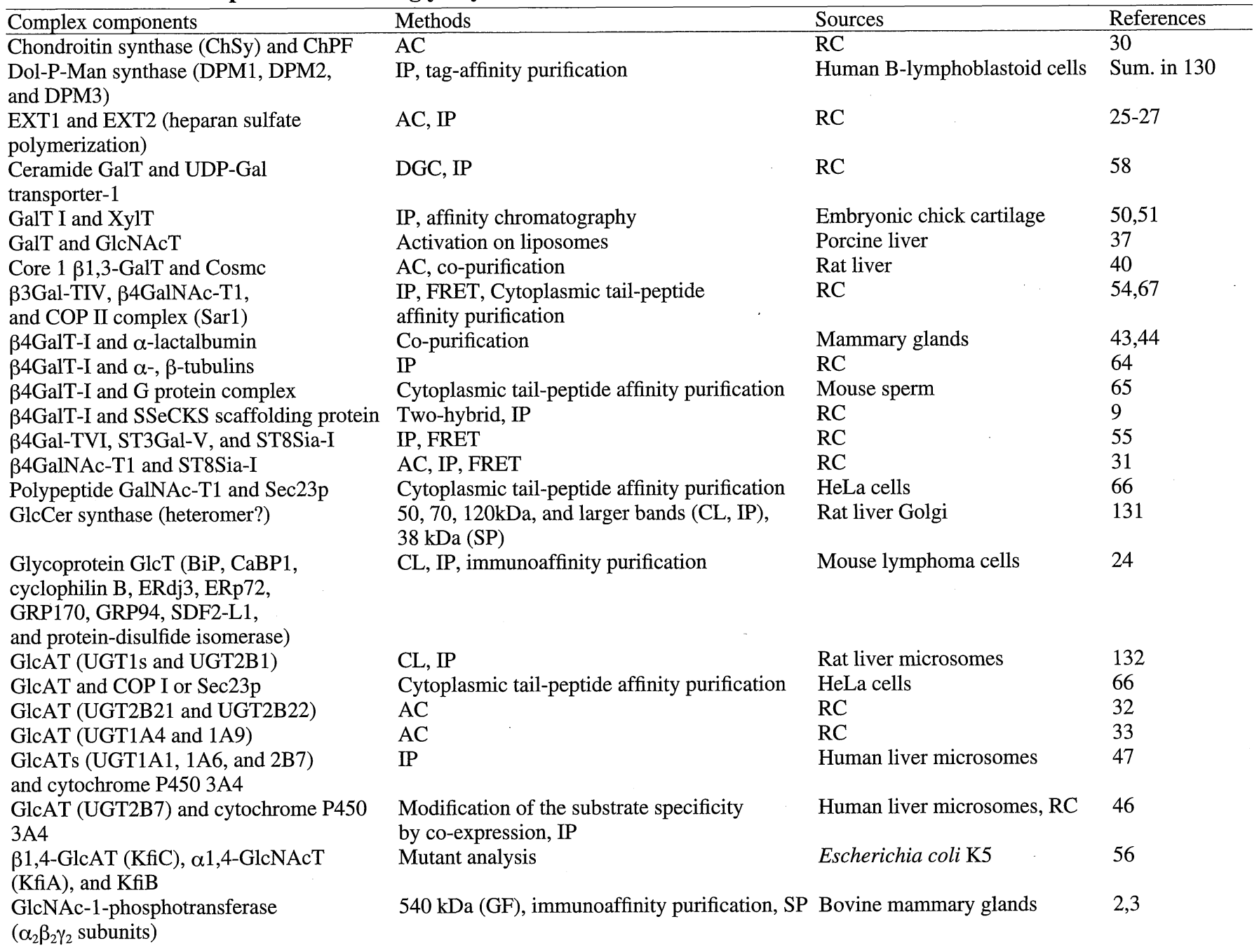


Peptide $O$-GlcNAcT (OGT)(heteromer?) Peptide $O$-GlcNAcT (OGT) and mSin3A (a corepressor)

Peptide $O$-GlcNAcT (OGT)

and GRIF-1 $\left(\mathrm{GABA}_{\mathrm{A}}\right.$ receptor-associated

protein) or its homolog, OIP106

Peptide $O$-GlcNAcT (OGT) and Ser/Thr

phosphatases

(PP1 $\beta$ and PP1 $\gamma$ )

Peptide $O$-GlcNAcT (OGT) and ataxin-10 $\alpha$-GlcNAcT (GPI-GnT) and Ras 2 $\alpha$-GlcNAcT (GPI-GnT)(DPM2,

GPI1, PIG-A, -C, -H, -P, and -Y)

$\beta 1,2$-GlcNAcT-I (GnT-I)

and mannosidase II

$\beta 1,3-G l c N A c T s$ ( $\beta 3 \mathrm{Gn}-\mathrm{T} 2$ and -8 )

$\beta 1,4-$ GlcNAcT (Alg13p and Alg14p)

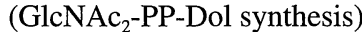

Mannan polymerase I (Mnn9p and Van1p)

Mannan polymerase II (Anplp,

Hoc1p, Mnn9p, Mnn10p, and Mnn11p)

Protein $O$-ManTs (Pmt1p and Pmt2p)

Protein $O$-ManTs (Pmt1p and Pmt2p;

Pmt $3 p$ and Pmt5p)(certain conditions,

Pmt1p and Pmt3p; Pmt2p and Pmt5p)

Protein $O$-ManTs (POMT1 and POMT2)

$\alpha 1,4-M a n T-I$ (GPI-MT-I)(PIG-M and -X)

$\beta 1,4-M a n T$ (Alg1p) and $\alpha 1,6-M a n T$

(Alg2p) or $\alpha 1,2-M a n T$ (Alg11p)

Oligosaccharyltransferase (Ost1p,

Ost2p, Ost3p, Ost4p, Ost5p,

Ost6p, Stt3p, Wbp1p, and Swp1p)

Oligosaccharyltransferase and translocon

(Sec61p, Sbh1p, and Sss1p)

Oligosaccharyltransferase (Ost1p

subunit) and $\beta 1,4-\mathrm{ManT}(\mathrm{Alg} 1 \mathrm{p})$

Oligosaccharyltransferase

(STT3-A/B, ribophorin I,

ribophorin II, OST48, DAD I,

Sec61 $\alpha \beta \gamma$, TRAP complex, DC2,

and KCP2)

PolySiaT (KpsC, KpsD, KpsE, KpsF,

KpsM, KpsS, KpsT, NeuA, NeuB, NeuC,

NeuD, NeuE, NeuS, and Omp)

tout-velu (TTV) and sister of tout-velu

(SOTV)

(heparan sulfate polymerization)

Uronosyl 2-O-SulT and

uronosyl 5-epimerase
$340 \mathrm{kDa}(\mathrm{GF}), 110$ and $78 \mathrm{kDa}$ (SP; 2:1)

Two-hybrid, IP, in vitro binding assay

IP, two-hybrid

Affinity purification

Rat brain

78

IP, two-hybrid

IP, inhibition of enzymatic activity

IP, tag-affinity purification

Relocation by microscopic analysis, DGC

$\mathrm{GF}$, activation by in vitro mixing

IP, complementary analysis

IP, two-hybrid

IP, tag-affinity purification

Immunoaffinity purification, AC

IP

$\mathrm{AC}$

IP, DNE, GF

CL, two-hybrid (split ubiquitin system)

CL, two-hybrid

Yeast

Yeast

Canine pancreatic microsomes

Blue-native PAGE, SP, LC-MS

Escherichia coli $\mathrm{K} 1$

Sum. in 59-62

AC, IP

$\mathrm{RC}$

28,29

IP, relocation by microscopic analysis

$\mathrm{RC}$

Yeast

11

69

uman B-lymphoblastoid cells

52,53

$\mathrm{RC} \quad 38$

$\mathrm{RC}$

RC $72,133,134$

RC, yeast 20,133, 134

Yeast 34

RC 73

$\mathrm{RC}-35,36$

Yeast Sum. in 12

$\mathrm{AC}$, enzymatic activation by simultaneous expression; $\mathrm{CL}$, analysis with cross-linking reagents; DGC, density-gradient centrifugation; DNE, dominant negative effect; FRET, fluorescence resonance energy transfer; GalT, galactosyltransferase; GalNAcT, $N$-acetylgalactosaminylt ransferase; GlcT, glucosyltransferase; GlcAT, glucuronosyltransferase; GlcNAcT, $N$-acetylglucosaminyltransferase; GF, gel filtration; IP, immunoprecipitation using with antibodies against enzymes or tag-peptides; ManT, mannosyltransferase; PP-Dol, dolichol diphosphate; RC, recombina

a possibility that certain protein(s) mediate the interaction of those proteins.

At any rate, I would like to note according to several functional categories. The most important biological significance of complex formation is about the localization of GTs in the Golgi apparatus, so called 'kin recognition' model. This notion is closely connected with complex formation, but
が必ずしも直接結合していることを意味しない、という点で ある。なぜならば両者の会合を介在するタンパク質が存在す る可能性があるからである。

ともかく幾つかの機能的カテゴリーに分類して話を進め たい。なお糖転移酵素の複合体形成の最も重要な生物学的意 義の一つは、糖転移酵素のゴルジ局在に複合体形成が関与し ていることである。いわゆる kin recognition モデルと複合体形 
I only address this briefly, so please refer to other papers (for example, ref 1).

\section{B. Analytical Methods}

The complex formation of GTs had been mainly suggested by enzyme purification. Evidence was brought from the detection of molecular forms bearing over twice greater molecular weights than those of monomers, by gel filtration, density gradient centrifugation, and SDS-PAGE in non-reducing condition. Subsets of those GTs form dimers or oligomers through disulfide bonds, because they behave as a monomer by SDS-PAGE in reducing condition. GlcNAc1-phosphotransferase is one of the most elegant examples in which the occurrence of a complex has been proved by purification. This enzyme is involved in the biosynthesis of Man 6-phosphate residues, a signal targeting lysosome; by this enzyme, GlcNAc-1-phosphate is transferred to the specific Man residue in $N$-glycans and then Man-6-phosphate is exposed by the action of specific $\alpha-N$-acetylglucosaminidase. Bao et al., partially purified the enzyme from bovine mammary glands and prepared several monoclonal antibodies against the enzyme fractions(2). They succeeded in purifying the enzyme complex by using an affinity column conjugated with a monoclonal antibody which inhibited the enzymatic activity. The complex is made up of six subunits $\left(\alpha_{2} \beta_{2} \gamma_{2}\right)$. The $\alpha$ and $\gamma$ subunits individually form homodimers through disulfide bonds, and two $\beta$ subunits non-covalently participate in the complex. Recently, Kudo et al., completed the determination of the amino acid sequences of the three subunits(3).

Radiation inactivation is also one of the effective methods to reveal complex formation. This method can evaluate molecular weights of protein complexes by measuring decreased enzymatic activities after application of various doses of radiation to samples(4). The advantage of this method is an ability to measure molecular weights even if target enzymes are in crude membrane fractions. Molecular weights of complexes of $\beta 1,4$-galactosyltransferase $(\beta 4 \mathrm{GalT})(5)$, UDP-glucuronosyltransferase(GlcAT)(6-8), or $\alpha 2,6$ sialyltransferase(SiaT)(5) were determined by this method. However, since it becomes clear that several GTs can catalyze a common reaction, it is necessary to consider carefully whether a target enzyme reaction is attributed to a single enzyme.

The two-hybrid method is popular for analysis of in vivo protein-protein interaction. The method has been utilized not only to confirm the binding of two target proteins, but to search for novel GT-binding proteins. For example, unexpected interaction between $\beta 4 \mathrm{Gal}-\mathrm{TI}$ and SSeCKS scaffolding protein(9), and between peptide $O-N$ acetylglucosaminyltransferase(GlcNAcT) and GRIF-1, its homolog OIP106(10), or ataxin-10(11), was found by two-
成は密接な関係にあるが、この話題についてはごく簡単に触 れるのみにとどめる。詳細については他の論文を参照された い(例えば文献 1)。

\section{B. 分析方法}

糖転移䤉素複合体の存在は古くは転移酵素の精製によっ て明らかにされてきた。すなわちゲルろ過や密度勾配遠心、 還元凰非存在下における SDS-PAGE などにおいてモノマーの 分子量に対して二倍以上の分子量を持つ分子種が検出される という結果から複合体の存在が示唆されてきた。このうち多 くの例はSDS-PAGEにおいて還元剤非存在下ではダイマー やオリゴマーであるが、還元剤存在下ではモノマーになるこ とから複合体形成にジスルフィド結合が関与していることが 考えられる。精製によって複合体の存在が証明された最も工 レガントな例として GlcNAc-1-リン酸転移酵素がある。この 酵素はリソソームへの輸送シグナルであるマンノース 6-リ ン酸の生合成に関わる酵素である。すなわち本酵素によって GlcNAc-1- リン酸が $N$ - 結合型糖鎖の特定のマンノース残基に 転移され、その後に $\alpha-N-$ アセチルグルコサミニダーゼの作用 によってマンノース 6-リン酸が形成される。Bao らは本酵素 をウシ乳腺より部分精製し、これを抗原として幾つかのモノ クローナル抗体を作成した。このうち酵素活性を阻害する抗 体を用いてアフィニティーカラムを作成し、複合体の完全精 製に成功した $(2)$ 。複合体は三種 $(\alpha 、 \beta 、 \gamma)$ のサブユニットが

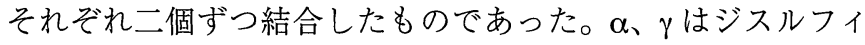
ド結合でそれぞれホモダイマーを形成し、 $\beta$ は非共有結合で二 分子結合していた。さらに近年 Kudo らによって全てのサブユ ニットのアミノ酸配列決定が完結した(3)。

Radiation inactivationも複合体の存在を証明する上で有力 な手法である。この方法は様々なレベルの放射線をサンプル に照射した際の酵素活性の減少の度合を測定することで会合 体の分子量を算出するものである (4)。この方法の長所は膜画 分などから酵素を精製すること無しに分子量を測定できるこ とにある。本法によって $\beta 1,4-$ ガラクトース転移酵素 ( $\beta 4 \mathrm{GalT})$ (5)、UDP-グルクロン酸転移䣲素 (GlcAT) (UGT) (6-8)、およ び $\alpha 2,6$ - シアル酸転移酵素 (SiaT) (5)の複合体の分子量がそれ ぞれ分析された。しかしながら近年同じ反応を触媒する転移 酵素が複数存在することが多くの例で明らかになってきたた め、膜画分の酵素活性が特定の酵素タンパク質のみに起因す るか否か慎重に判断する必要があろう。

Two-hybrid 法はタンパク質間相互作用の解析において最 も一般的な方法の一つである。本法は二つのタンパク質の結 合を証明する補強デー夕として使われるほか、転移酵素と結 合する夕ンパク質を広く検索する際にも有力である。例えば B4GalT-I と SSeCKS scaffolding protein との結合(9)、ペプチ ド O-N-アセチルグルコサミン転移酵素(GlcNAcT) (OGT) と GRIF-1 およびそのホモログである OIP106(10)や ataxin10 と の結合(11) (後述)など、予想を超えた会合体の存在の解明に 
hybrid method. Moreover, split ubiquitin system, a kind of two-hybrid method, is also powerful. In this method, two recombinant target proteins are simultaneously expressed; one construct fused with the N-terminal domain of ubiquitin(Nub) at the $\mathrm{N}$ - or C-terminal of one target protein, and the other construct fused with the C-terminal domain of ubiquitin(Cub) and thereafter a reporter protein(transcriptional factors) at the C-terminal of the other target protein. Nub is mutated at $\mathrm{Il}^{13}$ to $\mathrm{Gly}(\mathrm{NubG})$ or $\mathrm{Ala}(\mathrm{NubA})$ in order to decrease the affinity to $\mathrm{Cub}$, so that NubG/A and Cub can form split ubiquitin only when they are located quite closely by the association of the two target proteins. If both NubG/A and Cub are oriented in the cytosol and the two target proteins are associated with each other, NubG/A and Cub can bind and be recognized by ubiquitin ligase, resulting in the release of the reporter protein and the appearance of its phenotype. This method takes advantage in analyses of the interaction and topology of membrane protein complexes, such as oligosaccharyltransfera $\operatorname{se}(\mathrm{OT})(12)$.

Methods using fluorescent protein-fused constructs can serve analyses of in vivo and in situ interaction of proteins. In fluorescence resonance energy transfer(FRET) methods, each two target protein is fused with cyan fluorescent protein(CFP) or yellow fluorescent protein(YFP), alternatively green fluorescent protein(GFP) or red fluorescent protein(RFP), and the constructs are simultaneously expressed. If the target proteins can interact with each other, the fluorescent protein domains are located closely. When CFP(or GFP) is excited, the energy can be nonradiatively transferred to YFP(or RFP), which releases respective fluorescence. On the other hand, a fluorescent protein can be applied directly for a two-hybrid system. Nyfeler et al., reported a method which can reveal the interaction of intracellular proteins using two complementary polypeptide fragments of yellow fluorescent protein(YFP)(13). Two target proteins are fused with different YFP fragments and then the constructs are simultaneously expressed. If the two target proteins bind to each other, fluorescence can be detected by complementary binding of the two YFP fragments. This method will be powerful the for analysis of in vivo interaction of GTs.

The dominant negative effect should be considered when wild-type and inactive mutant enzymes are simultaneously expressed and the enzymatic activity is quite low as compared with the activity of wild-type alone. The effect is evidence of homo-complex formation because wild-type enzymes can be inactivated by binding to mutant enzymes. The effect has been found in a genetic disease(Crigler-Najjar syndrome, defect in UGT1A1)(14), a Drosophila mutant(fringe, defect in a $\beta 1,3-$ GlcNAcT)(15), and cultured cells with simultaneous expression[Alg1p(16), Alg1p and Alg2p/Alg11p(16), UGT1A1(17), UGT2B1(18),
役立っている。また two-hybrid 法の変法として split ubiquitin system も有力である。この方法では標的タンパク質の $\mathrm{N}$ 端も しくは C 端にユビキチンの $\mathrm{N}$ 端側領域 $(\mathrm{Nub})$ を融合させ、も う一方の標的タンパク質の C 端側にユビキチンの C 端側領域 (Cub) およびそれに続くレポータータンパク質(転写因子)を 融合させたコンストラクトを作成し、共発現させる。この際、 標的タンパク質同士が会合し、Nub と Cub が近接したときの み結合出来るように、Nubの $\mathrm{Ile}^{13}$ を Gly (NubG)もしくは Ala (NubA)に置換し、NubとCubのアフィニティーを下げてお く。NubG/A、Cub 領域が共に細胞質側に表出し、かつ両標的 タンパク質が会合体を形成した場合、NubG/A と Cub も結合 し、これを認識するユビキチンリガーゼによってレポーター タンパク質が切断・放出され、表現系が発現される。本法の 利点は膜タンパク質に適応出来ること、および膜タンパク質 のトポロジー解析が可能であることである。本法によって oligosaccharyltransferase (OT)の複合体解析および構成サブユニッ トのトポロジーが解析されている(12)。

蛍光タンパク質を融合させたリコンビナント体を用いた 手法もin vivo および in situでのタンパク質間相互作用の解析 に有力である。蛍光共鳴エネルギー移動法(FRET 法)では $2 つ$ の標的タンパク質にそれぞれ青色蛍光タンパク質(CFP) 拈よ び黄色蛍光タンパク質 (YFP)、もしくは緑色蛍光タンパク質 (GFP)および赤色蛍光タンパク質 (RFP)を融合させたコンスト ラクトを作成し、共発現させる。両者がきわめて近接して存 在する場合、CFPもしくは GFP を励起するとそのエネルギー が近傍の YFPもしくはRFPに移動し、最終的に後二者より蛍 光が放出されることを利用した解析法である。さらに蛍光夕 ンパク質を two-hybrid 様に応用した例として、最近 Nyfeler ら は yellow fluorescent protein (YFP)由来の二つのポリペプチド 断片を用いた細胞内タンパク質間相互作用の解析法を報告し ている(13)。解析対象の二つのタンパク質にそれぞれ異なる YFP 断片を融合させたリコンビナント体を共発現させる。二 者が細胞内で会合すると YFP 断片も近接し、相補的に結合し 蛍光を発するというエレガントな系である。細胞内における 糖転移酵素間の結合解析に威力を発揮するかも知れない。

野生型と活性の無い变異型の二種の酵素タンパク質が共 発現しているとき、野生型単独の発現に比べ酵素活性が大き く減少している場合、ドミナント・ネガティブ効果が考えら れる。変異型と結合することで野生型の活性も消失している という可能性が考えられるため、本効果は複合体形成の根拠 とされている。遺伝病や変異体として見い出された例として はクリグラー - ナジャー症候群 [Crigler-Najjar syndrome、UDPGlcAT 1A1 (UGT1A1) の欠損] (14) やショウジョウバエの fringe（31,3-GlcNAcT の欠損）(15)があり、細胞における共発 
Trends in Glycoscience and Glycotechnology Vol.18 No.101 (May 2006) pp.209-230

and GlcNAc-1-phosphotransferase(19)](described later).

Various tag-proteins and tag-peptides have been exploited. When a tag-fused target enzyme is expressed in cells, complexes bearing the target enzyme can be easily purified by immunoprecipitation or tag-affinity resins, and components of purified complexes can be identified by mass spectrometry or Western blotting. Cross-linking reagents are often used in order to recover weak-binding components with high yield. The occurrence of multimer complexes such as mannan polymerase II(M-Pol II)(Summarized in 20), $\alpha 1,6-$ GlcNAcT(GPI-GnT)(Summarized in 21 , and oligosaccharyltransferase(OT)-translocon supercomplex(Summarized in 22) have been shown by these methods. On the other hand, blue native-PAGE method is also valuable for isolation of large molecular weight complexes. This method was utilized for isolation and analysis of canine pancreas OT-translocon supercomplexes(23). $\alpha 1,3-$ glucosyltransferase(GlcT)-containing complexes, which are involved in quality control of new-born ER proteins, were isolated by unique methods(24). Mouse lymphoma $\mathrm{Ag} 8(8)$ cells express the immunoglobulin(Ig) heavy chains, but not the light chains, and thus accumulate the heavy chains in the ER. The $\alpha 1,3-G l c T$ complexes binding to incompletely folded heavy chains were easily purified by protein A-Sepharose, without expression of any tag-fused protein(24).

\section{Changes in Enzymatic Activities by Simultaneous Expression or in Vitro Mixing of Two GTs.}

Recently the occurrence of many GT families has been clear, based on homology in amino acid sequences. The enzymatic activities of some GTs, however, could not be detected or were quite low even if the enzyme proteins were properly expressed in cultured cells as membrane-bound forms or soluble forms. One reason is that substrates used were not appropriate for enzyme assays, and another reason is that the enzymatic activities appeared only when forming a complex with other GTs or non-GT proteins. Examples are EXT1 and EXT2 in mammals(25-27), and TTV and SOTV in Drosophila $(28,29)$, those responsible for elongation of backbone structure of heparan sulfate $(4 \mathrm{GlcA} \beta 1 \rightarrow 4 \mathrm{GlcNAc} \alpha 1$ $\rightarrow)_{\mathrm{n}}$, chondroitin synthase(ChSy and ChPF) for elongation of backbone structure of chondroitin(4GlcA $\beta 1 \rightarrow 3 \mathrm{GalNAc} \beta 1$ $\rightarrow)_{\mathrm{n}}(30)$, ST8Sia-I $\left(\mathrm{GD}_{3}\right.$ synthase) and $\beta 4 \mathrm{GalNAc}-\mathrm{T} 1\left(\mathrm{GM}_{2} /\right.$ $\mathrm{GD}_{2}$ synthase) for biosynthesis of gangliosides(31), UDPGlcATs for detoxication[UGT2B21 and UGT2B22(32), UGT1A4 and UGT1A9(33)], and protein $O$-mannosyltransferases(ManT)[Pmt1p and Pmt2p(34), POMT1 and POMT2 $(35,36)]$. These enzymes had weak or no enzymatic activity in single expression, but simultaneous expression of the pair enzymes induced much greater activities. However, the elevated enzymatic activities were not observed when in
現で立証された例として $\mathrm{Alg} 1 \mathrm{p}$ と $\mathrm{Alg} 2 \mathrm{p} / \mathrm{Alg} 11 \mathrm{p} 、 \mathrm{Alg} 1 \mathrm{p}$ 単独 (16)、UGT1A1 (17)、UGT2B1 (18)、GlcNAc-1-リン酸転移酵 素(19)などがある(後述)。

これまでに様々なタグタンパク質やタグペプチドが開発 されている。タグ付きタンパク質を細胞に発現させ、タグを 目印にして免疫沈殿もしくはアフィニティークロマトグラ フィーによって複合体を精製する。その後構成タンパク質を 質量分析やウエスタンブロットで分析するという手法が複合 体解析に広く用いられている。このとき複合体をより安定化 して回收するため、タンパク質架橋剤がしばしば併用される。 このような手法によりマンナンポリメラーゼ II（M-Pol-II）（20 に要約)、 $\alpha 1,6-G l c N A c T$ (GPI-GnT) (21に要約)、oligosaccharyltransferase (22 に要約) などの高次複合体のサブユニットの解 析がなされている。また複合体の精製法として、巨大分子の 分離、精製に優れている blue native-PAGE 法も有力であり、こ れによってイヌ膵臓の oligosaccharyltransferase 複合体の単離・ 分析がなされている(23)。また特殊例としては、小胞体内の 新生タンパク質の品質管理に関わる $\alpha 1,3-$ グルコース転移酵素 (GlcT) 複合体の精製がある。この例では、不完全な折りたた み構造を持つイムノグロブリン重鎖を蓄積する細胞株を利用 し、プロテイン A-Sepharose で Ig 重鎖 - 酵素複合体を精製する というユニークな方法がとられている(24)。

\section{C. 二種の糖転移酵素の共発現もしくはインビトロ混合による 酵素活性の変化}

近年糖転移酵素の遺伝子群がアミノ酸配列の相同性をも とに数多く明らかにされてきた。しかしある種の酵素につい ては、COS 細胞などに膜タンパク質として発現させたり、ま たは分泌型として発現させた場合、タンパク質ができている にもかかわらず酵素活性が検出出来ない。この原因の一つは 用いた基質が合っていないためと考えられるが、もう一つの 可能性は他の糖転移酵素と複合体を形成することで初めて活 性を発現出来るというものである。そのような例としてへパ ラン硫酸の基本骨格糖鎖(4GlcA $\beta 1-4 \mathrm{GlcNAc} \alpha 1$-) $\mathrm{n}$ の伸長に関 わるEXT1 およびEXT2(哺乳類) (25-27)、TTV およびSOTV (ショウジョウバエ) $(28 、 29$ )、コンドロイチンの基本骨格糖 鎖 $(4 \mathrm{GlcA} \beta 1-3 \mathrm{GalNAc} \beta 1-)_{\mathrm{n}}$ の伸長に関わるコンドロイチンシ ンターゼ(ChSy および ChPF) (30)、ガングリオシドの生合 成に関わる ST8Sia-I（GD シンターゼ）拉よび 34 GalNAc-T1 $\left(\mathrm{GM}_{2} / \mathrm{GD}_{2}\right.$ シンターゼ) (31)、解毒作用の一つであるグルクロ ン酸抱合を担う UDP-GlcAT [UGT2B21 およびUGT2B22(32)、 UGT1A4 およびUGT1A9(33)]、ポリペプチド鎖の $O$ - マンノ シル化に関わるプロテイン $O$-マンノース転移酵素 (ManT) [Pmt1p およびPmt2p（34）、POMT1 およびPOMT2 $(35,36)]$ が 
vitro mixing purified enzymes or crude membranes derived from individually transfected cells. This indicates that strict complex formation including disulfide bonds takes place.

On the other hand, it has been reported that in vitro mixing of two GTs enhances the catalytic activities. Ivatt reported that a GalT and a GlcNAcT which were purified from porcine liver as membrane-bound proteins, activated each other when concurrently reconstituted on liposomes(37). Although the grade of purification and enzymatic characters were not noted in the report, a possibility that efficient synthesis of Gal $\rightarrow$ GlcNAc $\rightarrow$ Man sequence is performed by interaction of GalT and GlcNAcT, is attractive with a view to substrate channeling. The author and Yamashita reported that a mixture at $1: 1$ ratio of soluble $\beta 1,3-\mathrm{GlcNAcT}-2(\beta 3 \mathrm{Gn}-\mathrm{T} 2)$ and $\beta 3 \mathrm{Gn}-\mathrm{T} 8$, which were produced by Pichia pastoris, bears several times higher enzymatic activity than the sum of the individual activities(38). $\beta 3 \mathrm{Gn}-\mathrm{T} 2$ and $-\mathrm{T} 8$ seem to form a heterodimer, from the result of gel filtration. The substrate specificities of both enzymes are similar. However, the mixture has more similar substrate specificity to $\beta 3 \mathrm{Gn}-\mathrm{T} 8$ than to $\beta 3 \mathrm{Gn}-\mathrm{T} 2$, suggesting the activation of $\beta 3 \mathrm{Gn}-\mathrm{T} 8$, which has much lower specific activity than $\beta 3 \mathrm{Gn}-\mathrm{T} 2$. Since the expression level of $\beta 3 \mathrm{Gn}$-T8 is significantly elevated in colon cancer(39), the enzyme may be involved in the elongation of poly- $N$-acetyllactosamine moieties in cancer cells. In contrast, a few reports showed that the enzymatic activities of the in vitro mixture of wild-type and inactive mutant type are quite a bit lower than that of wild-type alone. Dolichol phosphate GlcNAc-1-phosphotransferase(GPT) is an.ER-resident enzyme and responsible for the first step of the biosynthesis of lipid-linked oligosaccharides. Dan and Lehrman found the dominant negative effect of the enzyme in vitro, because the mixture of membrane fractions from wild-type-tranfected cells and inactive, mutant-type-transfected cells had lower enzymatic activity than the membrane fractions from wildtype-transfected cells alone(19). Similar results were obtained in the case of UGT1A1, a UDP-GlcAT(17).

Some non-GT proteins can stabilize and/or activate specific GTs. Ju and Cummings showed that Cosmc, which was co-purified with core $1 \beta 1,3-\mathrm{GalT}(\mathrm{C} 1 \beta 3 \mathrm{Gal}-\mathrm{T} 1)$, strongly enhances $\mathrm{C} 1 \beta 3 \mathrm{Gal}-\mathrm{T} 1$ activity when simultaneously expressed(40). They speculated that Cosmc functions as a chaperon molecule to stabilize $\mathrm{C} 1 \beta 3 \mathrm{Gal}-\mathrm{T} 1$ protein. Moreover, they reported that Cosmc gene is mutated in patients with $\mathrm{Tn}$ syndrome, which is a genetic disease deficient in core 1 structure(41). Similar results were reported for $\alpha 1,4-$ ManT-I(GPI-MT-I), which is responsible for the attachment of the first Man in the biosynthesis of GPI-anchor glycans. Ashida et al., showed that GPI-MT-I is composed of at least two proteins, PIG-M and PIG-X, which work as a catalytic subunit and its stabilizer, respectively(42).
ある。これらの例では、それぞれ単独で発現させた場合では 活性が弱いかもしくは検出できないのに対し、細胞内で共発 現させると酵素活性が劇的に増大する。一方二つのタンパク 質をそれぞれ単独で発現させて得られた精製タンパク質もし くは粗膜画分をインビトロで混合した場合、活性増大は見ら れない。このことからこれらの例ではタンパク質が生合成さ れる際、ジスルフィド結合を含めた複雑な複合体形成が行わ れるものと考えられる。

対照的に、インビトロで 2 種の酵素タンパク質を混合す ることにより触媒活性が増大する例が報告されている。Ivatt はブタ肝臓から膜タンパク質として精製した GalT と GlcNAcT をリポソーム上に再構成する実験により、2 種の酵素の共存 下で各々の触媒活性が増大することを見い出した (37)。精製 状態や酵素活性の性質についての記述が無いのが残念だが、 $\mathrm{Gal} \rightarrow \mathrm{GlcNAc} \rightarrow \mathrm{Man}$ の連続する反応過程において両酵素が 互いを活性化するという観点は substrate channeling の存在を連 想させ、興味深い。また著者抢よびYamashitaらはメタノー ル資生菌 (Pichia pastoris) を用いて可溶型の $\beta 1,3-G l c N A c T-2$

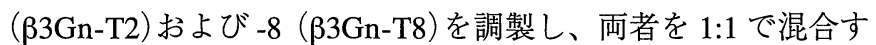
ると単独での合算值に比べ数倍酵素活性が増大することを明 らかにした(38)。またゲル濾過の結果から両者はへテロダイ マーを形成すると推測される。両酵素の基質特異性は似てい るが、混合物の特異性は $\beta 3 \mathrm{Gn}-\mathrm{T} 2$ より - 78 により近く、もと もと比活性の低い $\beta 3 \mathrm{Gn}-\mathrm{T} 8$ が活性化されている可能性が考え られるが詳細は明らかでない。大腸癌において $\beta 3 \mathrm{Gn}-\mathrm{T} 8$ の発 現量は顕著に増大するため(39)、B3Gn-T8 は癌細胞における ポリ $N$-アセチルラクトサミン鎖の伸長に関与しているかも知 れない。これとは逆に不活性な変異酵素と野生型酵素をイン ビトロで混合すると野生型の酵素活性が大きく減少する例が 報告されている。ドリコールリン酸 GlcNAc-1-リン酸転移酵 素 (GPT) は脂質中間体 $\left(\mathrm{Glc}_{3} \cdot \mathrm{Man}_{9} \cdot \mathrm{GlcNAc}_{2}\right.$-PP-Dol) の最初の生 合成過程 (GlcNAc-PP-Dol の合成) に預かる小胞体局在酵素であ る。Dan および Lehrman は本酵素の野生型を発現させた細胞 由来の膜画分と不活性な変異型を発現させた細胞由来の膜画 分を混合すると酵素活性が減少し、ドミナント・ネガティブ 効果がインビトロでも見られることを示した(19)。同様の効 果が UDP-GlcATの一種、UGT1A1 においても見い出されてい る(17)。

糖転移酵素ではないある種のタンパク質が特定の糖転移 酵素の安定化 / 活性化に寄与することが知られている。Ju およ

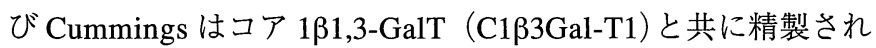
たタンパク質 Cosmc が C1 $1 \beta 3 \mathrm{Gal}-\mathrm{T} 1$ と共発現させることによ りその酵素タンパク質を安定化することを明らかにした (40)。 Cosmc は㧍そらくC $1 \beta 3 \mathrm{Gal}-\mathrm{T} 1$ タンパク質の安定性を高める シャペロン分子として機能していると考えられている。また Cosmc はコア 1 構造を合成出来ない $\mathrm{Tn}$ 症候群の原因遺伝子 であることが最近明らかにされた (41)。同様の結果が GPIア ンカー糖鎖の第一 Man 残基の付加に預かる $\alpha 1$,4-ManT-I（GPIMT-I)において報告されている。Ashida らはGPI-MT-Iが少な くとも PIG-M、PIG-X という二つのタンパク質を含む複合体 であり、前者が触媒サブユニットとして機能するのに対し、 
Substrate specificities of GTs can be modified by other GTs or non-GT proteins. $\beta 4 \mathrm{Gal}-\mathrm{TI}$ and $\alpha$-lactalbumin are one of the most dramatic and forerunning examples $(43,44)$. It is well-known that $\beta 4 \mathrm{Gal}$-TI recognizes GlcNAc as a much better substrate than Glc, while on the other hand in the presence of $\alpha$-lactalbumin, Glc is oppositely much better substrate for $\beta 4 \mathrm{Gal}-\mathrm{TI}$. Crystal structure of $\beta 4 \mathrm{Gal}-\mathrm{TI}$ and $\alpha$-lactalbumin complex has been revealed(45). On the other hand, some UDP-GlcATs(UGT) act on morphine, a representative analgesic, producing morphine-3-GlcA(M3G) and/or morphine-6-GlcA(M6G). The former has no analgesic activity, while the latter is active as well as free morphine and thus a pharmacologically important metabolite. UGT2B21 preferentially produces M3G, while UGT2B22 had little activity for morphine. However, simultaneous expression of UGT2B21 and UGT2B22 enhanced the production of M6G to an equal level to M3G(32). Similarly, M6G production via UGT2B7 was stimulated by co-expression with cytochrome P450(CYP) 3A4(46). CYP3A4 associates with other UGTs, at least UGT1A1 and 1A6(47), indicating that CYP3A4 may regulate some aspects of glucuronidation in the ER(described later). Further analysis for modification of substrate specificities of UGTs is expected.

\section{Substrate Channeling}

In certain metabolic pathway, two enzymes responsible for sequential reactions may form a complex. Substrate channeling is a notion that, after the first reaction finishes, a reaction product or an imtermediate is brought to the catalytic region of the second enzyme without release into solvent(reviewed in 48,49 ). The mechanism takes advantage in economical biosynthesis because of exhaustive use of an intermediate. Since glycan biosynthesis is in a stepwise manner, one could speculate that substrate channeling occurs in certain GTs. To date, however, there is no report to clearly show the existence of the substrate channeling mechanism in the biosynthetic pathways of glycans. Therefore we will note about candidates of possible pathways and GTs. Indeed, complex formation of sequential enzymes has been reported.

Schwartz et al., showed the interaction between xylosyltransferase (XylT) and $\beta 1,4 \mathrm{GalT}(\mathrm{GalT}-\mathrm{I})$, both of which are responsible for the early, sequential steps of glycosaminoglycan biosynthesis(50,51). XylT, but not GalT-I, bound to acceptor-conjugated affinity resin, while GalT-I bound to the resin to which XylT was pre-adsorbed. This result indicated the complex formation of sequentially acting GTs.

There are a few examples with respect to the biosynthetic pathway of $N$-linked glycans. Both GlcNAcT$\mathrm{I}(\mathrm{GnT}-\mathrm{I})$ and $\alpha$-mannosidase-II are localized in the medial Golgi and responsible for sequential steps in the processing of $N$-linked glycans. Nilsson et al., showed elegantly that,
後者は PIG-M の発現を安定化する役割を担っていることを明 らかにした(42)。

さらに二つの糖転移酵素の共発現もしくは糖転移酵素で はないある種のタンパク質と糖転移酵素の共発現(または混 合)によって、糖転移酵素の基質特異性が変化する例が報告さ れている。 $34 \mathrm{Gal}-\mathrm{TI}$ と $\alpha$-ラクトアルブミンは最も古く見いだ された複合体の例であり、かつ最も明快な相互作用をする例 の一つである $(43 、 44)$ 。周知のように $\alpha$-ラクトアルブミン非 存在下では $\beta 4 \mathrm{Gal}$-TI は GlcNAcを良い受容体基質とし Glcに はほとんど作用しないが、 $\alpha-$ ラクトアルブミンと結合すると 逆に Glc を良い基質とする。さらに $\beta 4 \mathrm{Gal}-\mathrm{TI}$ と $\alpha$-ラクトア ルブミンの結合はX $\mathrm{X}$ 線結晶構造解析によっても明らかにされ た(45)。またある種の UDP-GlcAT（UGT）は代表的な鎮痛剤 であるモルヒネのグルクロン酸抱合を行うが、グルクロン酸 の修飾型としてモルヒネ-3-グルクロン酸 (M3G) とモルヒネ -6-グルクロン酸 $(\mathrm{M} 6 \mathrm{G})$ が生成する。前者が鎮痛作用を示さな い不活性型であるのに対し、後者は非修飾型同様活性型であ り、薬理学的に重要な修飾化合物である。UGT2B21は単独で はM $3 \mathrm{G}$ をより効率的に生成する。しかし単独では䤏素活性 の無いUGT2B22 と共発現させると M3G と M6G の両者が同 程度に生成することが判った(32)。同様にUGT2B7 はチトク ローム P450 3A4 と共発現させると単独での発現の場合に比心゙ M6G 合成に特異性がシフトすることが示された(46)。チトク ローム P450 3A4 は UGT1A1、1A6 とも会合することが明らか となっており (47)、小胞体におけるグルクロン酸抱合を調節 する重要な役割を担っていることが考えられる(後述)。更な る特異性の解析が期待される。

\section{Substrate Channeling}

ある代謝経路において、連続する二つの反応を担う酵素 同士が複合体を形成している例が知られている。第一の反 応が終わった後、反応産物もしくは中間体が酵素タンパク 質複合体を離れることなく次の反応の触媒領域へ手渡され るという分子機構が提唱されている (substrate channeling)(総 説 48、49)。このような機構の長所として、中間基質が溶液中 に分散することが無いため、より速やかで効率的な生合成を 行い得る。糖鎖の生合成は逐次的に行われるため、substrate channeling が糖鎖生合成に関わる酵素群においても起こってい る可能性が考えられる。しかしながら、現在のところ糖鎖生 合成経路について substrate channeling の存在が明快に示された 例は無い。よって本章ではその可能性のある経路・酵素につ いて概観したい。実際、連続する反応に携わる酵素の複合体 形成が幾例か報告されている。

Schwartz らはグリコサミノグリカン鎖の生合成の初期過程 に預かるキシロース転移酵素 (XylT) と続く $\beta 1,4-G a l T$ (GalT-I) が相互作用することを示した $(50 、 51)$ 。受容体基質を固定した アフィニティー樹脂にXylT は結合するが GalT-I は結合しな い。しかし予めXylT を吸着させたアフィニティー樹脂には GalT-I は結合した。この結果から連続する反応を触媒する二 
Trends in Glycoscience and Glycotechnology Vol.18 No.101 (May 2006) pp.209-230

when one enzyme fused with an ER-retaining sequence was expressed, a subset of the other wild-type enzyme was also localized in the ER, suggesting the interaction between the two enzymes $(52,53)$. These experiments provided a kin recognition model. This model is that Golgi-resident enzymes responsible for sequential 'kin' reactions form large molecular weight complexes, by which the enzymes are retained there $(52,53)$

$\mathrm{Alg} 1 \mathrm{p}$ is a $\beta 1,4-$ mannosyltransferase(ManT) acting on $\mathrm{GlCNAc}_{2}$-PP-Dol. Gao et al., reported the association between Alg1p and $\alpha 1,6-M a n T(A l g 2 p)$ or $\alpha 1,2-M a n T(A l g 11 p)(16)$. There are at least two hetero-complexes containing Alg1p; one further includes Alg2p and the other includes Alg11p. They also showed that Alg1p can form homo-oligomer, too. Although Alg1p and Alg11p are not involved in sequential reactions, they speculated that Alg1p serves to present ManPP-Dol to Alg11p by binding to the dolichol moiety, otherwise to directly activate $\mathrm{Alg} 11 \mathrm{p}$ activity.

Biosynthesis from GlcCer to $\mathrm{GD}_{3}$ requires sequential reactions by $\beta 1,4-\mathrm{GalT}(\beta 4 \mathrm{Gal}-\mathrm{TVI}), \alpha 2,3-$ SiaT(ST3Gal-V), and $\alpha 2,8-S i a T(S T 8 S i a-I)$. Similarly, $\beta 1,4-$ GalNAcT( $\beta 4$ GalNAc-T1) and $\beta 1,3-G a l T(\beta 3 \mathrm{Gal}-\mathrm{TIV})$ are responsible for the biosynthesis from $\mathrm{GM}_{3}$ to $\mathrm{GM}_{1}$. Giraudo et al., showed that there exist at least two complexes concerning ganglioside biosynthesis, one containing $\beta 4 \mathrm{Gal}-$ TVI, ST3Gal-V, and ST8Sia-I, and the other containing $\beta 4 \mathrm{GalNAc}-\mathrm{T} 1$ and $\beta 3 \mathrm{Gal}-\mathrm{TIV}(54,55)$. In the complex of the former three enzymes, it was suggested that $\beta 4 \mathrm{Gal}-\mathrm{TVI}$ and ST8Sia-I are not directly associated with each other and that ST3Gal-V mediates the association of the both enzymes, in accordance with the biosynthetic sequence of $\mathrm{GD}_{3}$. They also showed that their $N$-terminal regions including the cytoplasmic tail, transmembrane region, and stem region are sufficient for both the complex formations. In contrast, Bieberich et al., showed the association of $\beta 4$ GalNAc-T1 and ST8Sia-I. The two enzymes can enhance the enzymatic activities of each other, by simultaneous expression(31).

Hodson et al., showed the association between $\beta 1,4-$ GlcAT(KfiC) and $\alpha 1,4-G l c N A c T(K f i A)$, both of which cooperatively synthesize capsule polysaccharides $(4 \mathrm{GlcA} \beta 1$ $\rightarrow 4 \mathrm{GlcNAc} \alpha 1 \rightarrow)_{\mathrm{n}}$ in $E$. coli $\mathrm{K} 5(56)$. The biosynthesis of this polymer differs from that of chondroitin or backbone glycans of heparan sulfate, since the latter were polymerized by hetero-complexes, each subunit of which contains two catalytic regions with different substrate specificities.

Pinhal et al., showed the association between uronosyl 2-O-sulfotransferase(SulT) and uronosyl 5-epimerase, both of which are responsible for modification of backbone glycans of heparan sulfate(57). When one enzyme was fused with an ER-retaining signal and the construct was expressed, the other wild-type was also retained in the ER. Since the enzymatic
つの酵素の複合体形成が示唆された。

$N$ 結合型糖鎖の生合成過程においても、連続する反応を担 う酵素タンパク質同士が複合体を形成している例が示されて いる。 $\beta 1,2-G l c N A c T-I$ (GnT-I) と $\alpha$ - マンノシダーゼ-II は medial ゴルジに局在し、 $N$ 結合型糖鎖のプロセシング過程の連続 する反応を担う酵素である。Nilssonらは片方のタンパク質に 小胞体局在タグを融合させたリコンビナントを発現させると、 もう一方の野生型タンパク質の局在性も小胞体に移行すると いう巧妙な実験によって複合体形成を明らかにした $(52 、 53)$ 。 これは kin recognition モデルを支持する重要な知見となって いる。kin recognition モデルとはゴルジ体に局在する酥素夕 ンパク質が類縁反応を触媒するもの同士互いに大きな複合体 を形成することによって局在性を維持するというものである $(52,53)$ 。

Alg1p は GlcNAc 2 -PP-Dol に作用する $\beta 1,4-M a n T$ である。 Gao らは Alg1p とその後の反応を担う $\alpha 1,6-M a n T$ (Alg2p)、

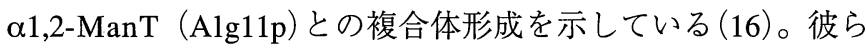
は Alg1p を含む少なくとも二種類の複合体が存在し、一方は さらに $\mathrm{Alg} 2 \mathrm{p}$ を含み、もう一方はさらに $\mathrm{Alg} 11 \mathrm{p}$ を含むことを 示した。また Alg1pが単独でホモオリゴマーを形成し得るこ

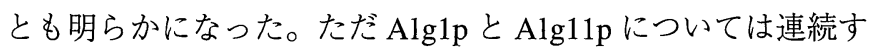
る反応を担っているわけではないが、 $\operatorname{Alg} 1 \mathrm{p}$ の役割として、オ リゴ糖-PP-Dolのドリコール残基を認識し Alg11p へ受容体基 質を提示する可能性もしくは Alg11p の活性化の可能性が推測 されている。

グルコシルセラミドから $\mathrm{GD}_{3} へ$ の生合成には $\beta 1,4-$ GalT ( $\beta 4$ GalT-VI)、 $\alpha 2,3-$ SiaT (ST3Gal-V)、および $\alpha 2,8$-SiaT (ST8Sia-I)による連続した反応が必要である。また $\mathrm{GM}_{3}$ か ら $\mathrm{GM}_{1}$ への生合成には $\beta 1,4-$ GalNAcT (B4GalNAc-T1) 㧤よび

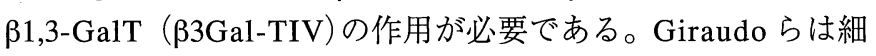
胞内で前三者抢よび後二者がそれぞれ別個の会合体を形成し ていることを明らかにした $(54 、 55)$ 。なお前三者の会合体につ いては B4GalT-VI と ST8Sia-I は直接会合せず、ST3Gal-Vを介 して複合体を形成していることが示唆されている。また、こ れら会合体の形成には細胞質領域、膜貫通領域およびステム 領域を含む $\mathrm{N}$ 端側領域が関わっているらしい。一方で、Bieberich らは 34 GalNAc-T1 と ST8Sia-I の会合体形成を示してい る。両者は共発現することにより互いの酵素活性を増大させ 得ることが証明されている(前述) (31)。

また、Hodson らは大腸菌 K5 株の夾膜多糖 (GlcA 1 14GlcNAc $\alpha 1-4)_{\mathrm{n}}$ の合成に関わる $\beta 1,4-G l c A T$ (KfiC) と $\alpha 1,4-$ GlcNAcT（KfiA）が会合体を形成することを示した(56)。この 例では二種の酵素タンパク質が交互に作用しポリマーを合成 すると考えられるが、コンドロイチンやへパラン硫酸の主鎖 の生合成では一つの酵素タンパク質が二つの転移酵素領域を 持っている点で異なっている。

Pinhal らはヘパラン硫酸主鎖の修飾に関わるウロノシル 2-O - 硫酸転移酵素 $($ SulT $)$ とウロノシル 5- エピメラーゼが会合 していることを明らかにした(57)。両者はゴルジ局在酵素で 
activity of the 5-epimerase was enhanced by simultaneous expression of uronosyl 2-O-SulT, the SulT could directly stabilize and/or activate the 5-epimerase.

Sugar-nucleotides, one of the substrates for GTs, are translocated from cytosol to the inner side of the ER or the Golgi apparatus by specific transporters. However, little is known whether transported sugar-nucleotides diffuse in the lumen and then they are captured by GTs, or they are passed by transporters to GTs directly. Sprong et al., reported the association of ceramide GalT(GalT-I) and UDP-Gal transporter1(UGT1)(58). GalT-I is a type I membrane protein, arranging the catalytic domain in the luminal side of the ER and an ER-resident signal in the cytoplasmic region. Usually UGT1 resides in the Golgi apparatus, but when GalT-I was simultaneously expressed, a subset of UGT1 was shifted to locate in the ER, indicating the association of the two proteins.

Cytochrome P450(CYP) and UDP-GlcAT(UGT) are important for the detoxication system of cells. Toxics and chemical compounds invading or produced in cells are primarily oxidized by CYPs on the cytosolic face of the ER, and are driven outside of cells following glucuronidation via UGTs or sulfation. Since in rare cases, oxidatives produced by CYPs are toxic or carcinogenic, they should be immediately detoxified by UGTs or SulTs. From this viewpoint, the interaction between CYPs and UGTs has been tested, and in fact, CYP3A4 exhibits the association with several UGTs and can modify the substrate specificity of UGT2B7 $(46,47)$. However, since catalytic domains of UGTs is oriented to the lumenal side of the ER, it would be a prerequisite that there exist certain transporter(s) to translocate oxidized intermediates across the ER membrane.

At any rate, to assess the existence of a substrate channeling system in the biosynthetic pathways of glycans, ultrastructural studies for GT complexes are indispensable. It is quite an attractive subject to assess how kin enzymes recognize their partners, and how catalytic regions of component enzymes are arranged in complexes. In addition, it should be clarified by in vitro enzymological studies whether intermediates are liberated from complexes after the earlier reaction or not, although these studies will be hard to solve because all target enzymes are membrane-integrated.

The occurrence of large machinery containing about a dozen subunits and involved in complicated biological processes has been reported. (i) With regard to polysialic acids, one of the capsular polysaccharides in E. coli $\mathrm{K} 1$ and K5 strains, large supercomplexes synthesize sialic acids and polymerize them on the inner face of cytoplasmic membrane, and further translocate the new-born polymers to outside across the inner and outer membranes(59-62). (ii) Meunier et al., showed that $\alpha 1,3-\mathrm{GlcT}$ which is involved in quality control for new-born proteins, is observed in complexes
あるが、一方に小胞体局在夕グをつけで発現させるともう一 方も小胞体局在に移行した。また5-エピメラーゼ活性はウロ ノシル 2-O-SulT の共発現によって増大することから、ウロノ シル 2-O-SulT が 5- エピメラーゼの安定化、活性化に寄与して いることが示唆された。

糖転移酵素の基質である糖ヌクレオチドは特異的トラン スポーターによって細胞質から小胞体またはゴルジ体内腔側 へ輸送される。内腔側へ移行した糖ヌクレオチドは一度拡散 した後に糖転移酵素に捕捉され利用されるのか、もしくはト ランスポーターから糖転移酵素へ直ちに渡され利用される のかは現在明らかでない。しかし Sprong らはセラミド GalT (GalT-1) と UDP-Gal トランスポーター1(UGT1)の会合を報告 している(58)。GalT-1 は I 型膜タンパク質で小胞体内腔側に 触媒領域を持ち、細胞質領域に小胞体局在シグナルを持って いる。UGT1 はゴルジ体に局在するトランスポーターであるが GalT-1 と複合体を形成し、一部が小胞体へ留まることが示唆 されている。

チトクロームP450 と UDP-GlcAT（UGT）は共に細胞の 解毒機構において重要な酵素である。細胞内の外来性・内因 性の毒物や薬物は小胞体の細胞質側に存在するチトクローム P450 によって酸化され、さらにUGT によるグルクロン酸抱合 やSulT による硫酸抱合が施され細胞外一排出される。チトク ローム P450 によって生じた酸化物の中には癌原性など毒性の 高い物質も存在し、次のグルクロン酸化が速やかに為される ことが重要である。この視点からチトクローム P450 と UGT の相互作用が研究され、実際に複合体形成や前述のような基 質特異性への影響が見い出された $(46 、 47)$ 。ただ UGT は小胞 体の内腔側に触媒領域を持つため両者のみでは連続反応は考 えにくく、さらに酸化物の膜透過に関わるトランスポーター の介在が推測される。

以上のように substrate channeling の存在を明らかにしてい く上で今後必要なことはやはり複合体の立体構造解析に尽き るであろう。類縁タンパク質が互いをどのペプチド領域でど のように認識し結合するのか、そして複合体における触媒領 域の位置関係はどのようになっているか興味深い課題である。 また同時にインビトロでの酵素学的解析、すなわち中間体基 質は第一の反応後複合体を離れるのか否かについて明らかに しなければならない。ただ相手が膜タンパク質であるだけに 大変困難な課題である。

さらに、十数種のタンパク質から成り、より複雑な生物 過程を担う巨大複合体の存在が示唆されている。(i) E. coli K1 株や K5 株の萊膜多糖の一種であるポリシアル酸の生合成で あるが、まず細胞膜内面においてシアル酸自体の合成からシ アル酸の重合までが一連の酵素の複合体によって行われ、生 成したポリマーは内膜および外膜を併せ貫くポリシアル酸輸 送複合体を通じて外膜外側へ輸送される。これら一連の合成、 輸送システムの存在が示唆されている(59-62)。(ii) Meunier らは新生タンパク質の品質管理に関わる UDP-GlcT が、小胞 体内腔の種々のシャペロンタンパク質から成る複合体に存在 
of several chaperon proteins in the lumen of the ER(24). Interestingly, they noted that the complexes do not contain calnexin/calreticulin. (iii) Oligosaccharyltransferase(OT) is well-known to be made up of multiple subunits. Lennarz's laboratory has extensively clarified the association and topology of OT subunits by in vitro cross-linking experiments and in vivo split ubiquitin system(summarized in 12). They suggested that the results obtained from the former methods reflect the organization of OT complexes in a condition without nascent protein substrates, and those from the latter method reflect in a working condition with substrate-binding. It has been recently shown that OT complexes associate with translocon complexes, which are the machinery to translocate nascent polypeptides into the lumen of the ER(22,23). (iv) In addition, by using cross-linking reagents, Yan $e$ t al., showed that Ost1p, a subunit of OT complexes in yeast, are located close to $A \lg 1 \mathrm{p}(\beta 1,4-\mathrm{ManT})(63)$. They provided the possibility that lipid-linked oligosaccharides $\left(\mathrm{Glc}_{3} \cdot \mathrm{Man}_{9} \cdot \mathrm{GlcNAc}_{2}-\mathrm{PP}\right.$ Dol) may be synthesized in close proximity to OT complexes and immediately be passed to them.

\section{E. Proteins Binding to the Cytoplasmic Tails of Golgi- Resident GTs}

Golgi-resident GTs generally possess a short cytoplasmic tail. To assess the biological roles of the short peptides, it is important to search for proteins binding to them. Yamaguchi and Fukuda prepared chimera proteins, which contain the cytoplasmic tail, transmembrane region, and stem region of $\beta 4 \mathrm{Gal}-\mathrm{TI}$, and replaced its catalytic domain with the extracellular domain of transferrin receptor or human chorionic gonadotropin $\alpha$ subunit. They showed that the chimera proteins associate with $\alpha$ - and $\beta$-tubulins(64). Since tubulins are cytosolic proteins, the cytoplasmic tail would be involved in the association. This result implied that the cytoskeletal system may control transporting and/or retaining of $\beta 4 \mathrm{Gal}-$ TI to the Golgi. On the other hand, using a cytoplasmic tailconjugated affinity column, Shur's laboratory showed that G protein complex binds to the peptide region of $\beta 4 \mathrm{Gal}-\mathrm{TI}(65)$. They proposed the possibility that when $\beta 4 \mathrm{Gal}-\mathrm{TI}$ on the cell surface of mouse sperm binds to egg coat protein ZP3 and forms aggregates itself, $G$ protein complex attached to the cytoplasmic tail is then activated and transmits signals leading to acrosome reaction. Moreover, they identified SSeCKS(Src suppressed $C$ kinase substrate) scaffolding protein as a binding protein to the cytoplasmic tail of $\beta 4 \mathrm{Gal}-\mathrm{TI}$ by two-hybrid method(9). The SSeCKS resides in perinuclear sites and the inner surface of cytoplasmic membrane, and is involved in the control of the cytoskeletal system. One attractive possibility is that the SSeCKS could serve to bring Golgi-resident $\beta 4 \mathrm{Gal}-\mathrm{TI}$ to the cell surface.

COP I- and COP II-coated vesicles are responsible for
することを示した (24)。興味深いことにこの複合体にはカル ネキシン/カルレティキュリンは含まれていない。(iii) oligosaccharyltransferase (OT) は最も良く研究されているタンパク 質複合体の一つである。Lennarz のグループは、in vitro におけ る架橋剤を用いた実験、およびin vivo における split ubiquitin system を用いた実験により、OT のサブユニット間の会合およ びトポロジーについて多くの知見を得た(12)。彼らは前者は 新生タンパク質基質を持たない状態の高次構造を、そして後 者は基質を結合した活動状態の高次構造を反映していると推 測している。また、小胞体に抢いて新たに合成されたポリぺ プチド鎖を内腔側へ移すトランスロコン複合体と OT 複合体が 会合していることが最近示された(22、23)。(iv) Yan らは架橋 剤を用いた実験により、酵母の OT 複合体の構成サブユニット の一つ Ost1p が Alg1p（ $\beta 1,4-\mathrm{ManT}$ ) と近接していることを示し た (63)。このことから脂質中間体 $\left(\mathrm{Glc}_{3} \cdot \mathrm{Man}_{9} \cdot \mathrm{GlcNAc}_{2}\right.$-PP-Dol) の生合成が OT の近傍で行われ、オリゴ糖が効率良く新生タン パク質へ転移されるシステムの存在が推測されている。

\section{E. 糖転移酵素の短い細胞質領域に結合するタンパク質}

ゴルジ体に局在する糖転移酵素は通常細胞質側に短いぺ プチド部分を持っている。このペプチドの生理的意義を調べ るには結合タンパク質を見つけることが肝要である。Yamaguchi およびFukuda は $\beta 4 \mathrm{Gal}$-TI の細胞質領域からステム領域ま でを持ち、触媒領域をトランスフェリンの細胞外領域もしく はヒト chorionic gonadotropin $\alpha$ サブユニットに置換したキメラ タンパク質が $\alpha-, \beta-$ チューブリンと会合することを見い出した (64)。チューブリンは細胞質タンパク質であることから、細 胞質領域が結合に関与すると考えられる。このことは $\beta 4 \mathrm{Gal}-$ TI のゴルジ体への移行、保持に細胞骨格が関わっていること を推測させる。一方 Shur のグループは $\beta 4 \mathrm{Gal}-\mathrm{TI}$ の細胞質領 域ペプチドを結合させたアフィニティーカラムを用い、G夕 ンパク質複合体がその細胞質領域に結合することを明らかに した (65)。彼らはマウス精子表面に存在する $\beta 4 \mathrm{Gal}-\mathrm{TI}$ が卵子 の被覆タンパク質 ZP3 に結合し会合体を形成すると、細胞質 側に結合している Gタンパク質複合体が活性化され、先体反 応につながるシグナル伝達を行なうという仮説を提唱してい る。さらに彼らは two-hybrid 法により B4Gal-TI の細胞質領域 と結合するタンパク質をマウス精巣 cDNA ライブラリーから 探し、SSeCKS (Src suppressed C kinase substrate) scaffolding 夕 ンパク質を同定した(9)。SSeCKS は細胞膜内面や perinuclear sites に局在するタンパク質で細胞骨格系の制御に関与してい る。SSeCKS は $\beta 4 \mathrm{Gal}-\mathrm{TI}$ をゴルジ体から細胞表面へ移行させ ることに関わっていることが推測されている。

小胞体とゴルジ体の間の小胞輸送には COP I および COP II 被覆小胞が関与する。前者はゴルジスタック間もしくはゴ ルジ体から小胞体への逆行輸送に関わり、後者は小胞体から 
cargo transport between the ER and the Golgi. The former acts on retrograde transport between the Golgi stacks or from the Golgi to the ER, while the latter acts on anterograde transport from the ER to the Golgi. Both COP I and COP II consist of several proteins. COP II complex is composed of a $\mathrm{G}$ protein Sar1 and two heterodimers, Sec23p/Sec24p and Sec13p/ Sec31p. Dominguez et al., showed that the cytoplasmic tail of a UDP-GlcAT(UGT, ER-resident and type I membrane protein) associates with COP I complex and Sec23p, whereas that of polypeptide GalNAc-T1(Golgi-resident and type II membrane protein) associates only with Sec23p(66). The cytoplasmic tail of the UGT bears a KKXX motif, which is important for COP I to recognize type I membrane proteins. This can explain the ER-residence of the UGT. On the other hand, Giraudo and Maccioni reported that the cytoplasmic tails of $\beta 4$ GalNAc-T1 and $\beta 3 \mathrm{Gal}-\mathrm{TIV}$, enzymes responsible for $\mathrm{GM}_{1}$ synthesis, exhibit the association with Sar1(67). They pointed out a dibasic motif in cytoplasmic tails, $[\mathrm{RK}](\mathrm{X})[\mathrm{RK}]$, which is positioned closely proximal to transmembrane regions and present in almost all type II, Golgi-resident GTs. They showed that localization of the two enzymes is shifted from the Golgi to the ER by deletion of this motif, and that the cytoplasmic peptides lacking this motif fail to bind to Sar1. These results suggested that Golgiresident GTs bearing the dibasic motif exit from the ER by binding to COP II complex.

As described above, cytoplasmic tail-binding proteins are involved in the transport of GTs, and with a view to GTs as a cell-surface receptor, the cytoplasmic tails work as an element to transmit extracellular glycan signals into cytoplasm.

\section{F. Biological Roles of Other GT Complexes}

To reveal functional differences between monomer and oligomer is an important approach for considering the biological significance of complex formation. Ma and Colley showed that $\alpha 2,6$-SiaT(ST6Gal) prepared from rat and bovine liver exists as a monomer and dimer(68). Interestingly, when the two forms are partially separated by glycerol densitygradient centrifugation, little enzymatic activity is detected in dimer fractions. Both the monomer and dimer bind to galactose-Sepharose and asialofetuin-Sepharose, but the dimer fails to bind to CDP-hexanolamine-agarose, as not in the case of monomer. From these results, it was speculated that ST6Gal dimer, which has quite a lower affinity for CMP-Neu5Ac than the monomer, loses the catalytic activity and functions as a galactose-binding lectin.

GPI-GlcNAcT(GPI-GnT) complex catalyzes the addition of $\alpha 1,6-$ GlcNAc to phosphatidylinositol, which is the first step in the production of GPI-anchor(21). The reaction is performed on the cytosolic face of the ER. In mammals, GPI-GnT is composed of at least seven proteins(DPM2, GPI1, PIG-A, -C, -H, -P, and -Y), while in yeast, of at least
ゴルジ体への輸送に関わるとされている。COP I および COP II はそれぞれ複数のタンパク質からなる複合体である。こ のうち COP II 複合体は G タンパク質 Sar1 と Sec23p/Sec24p、 Sec13p/Sec31pの二種のへテロダイマーから構成される。 Dominguez らは UDP-GlcAT（UGT, 小胞体局在、I 型膜タンパ ク質)の細胞質領域ペプチドがCOP I 複合体や Sec23p と会合 するのに対し、ポリペプチド GalNAc-T1 (ゴルジ局在、II 型膜 タンパク質)の細胞質領域ペプチドは Sec23p とのみ会合する ことを示した(66)。UGT の細胞質領域は、COP I がI型膜夕 ンパク質を認識するための KKXX モチーフを持っており、そ の小胞体局在が説明された。一方 Giraudo および Maccioni は $\mathrm{GM} 1$ 合成に関与する $\beta 4 \mathrm{GalNAc-T} 1$ と $\beta 3 \mathrm{Gal}-\mathrm{TIV}$ の細胞質領域 がCOP II 複合体の構成ユニットの一つ Sar1 と結合すること を示した (67)。彼らは II 型膜タンパク質であるゴルジ局在糖 転移酵素のほとんどが膜貫通領域近傍の細胞質領域にdibasic motif: $[R K](X)[R K]$ を持っていることに着目し、このモチー フを欠失させると酵素の局在性がゴルジ体から小胞体へシフ トすることを明らかにした。またこのモチーフを欠失させた 細胞質領域ペプチドは Sar1への結合能を失った。これらの結 果から糖転移酵素は細胞質領域に存在するシグナルをもって 小胞輸送に関与する細胞質タンパク質と結合し、小胞体もし くはゴルジ体への局在が保持されていることが示唆された。

以上のように細胞質領域結合タンパク質は糖転移酵素の 局在性に深く関わっている例が多い。また糖転移酵素が受容 体基質を認識・結合する細胞表面レセプターとして機能して いる場合、細胞質領域は外界からの糖鎖情報を細胞内に送る エレメントとして捉えられる。

\section{F. その他の糖転移酵素複合体の意義}

複合体形成の意義を考える上で、モノマーとオリゴマー の機能的相違を明らかにすることは大変重要なアプローチで ある。MaおよびColleyらはラットおよびウシ肝臓から調製 した $\alpha 2,6 \mathrm{SiaT}$ はダイマーおよびモノマーとして存在すること を示した(68)。興味深いことに両者をグリセロール密度勾配 遠心で分画した際、モノマーには酵素活性が見られるがダイ マーには活性がほとんど見られなかった。またモノマーおよ びダイマーは共にガラクトース -Sepharose やアシアロフェツ イン -Sepharose カラムに結合する。しかし CDP-ヘキサノール アミン -agarose カラムに対しては、モノマーは結合するがダ イマーは結合しなかった。以上の結果から $\alpha 2,6 \mathrm{SiaT}$ ダイマー は CMP-Neu5Acへの結合能が減弱することで酵素活性を失い、 細胞内でガラクトース結合レクチンとして機能していること が推測された。

ホスファチジルイノシトールへの $\alpha 1,6-G 1 c N A c$ 付加は GPI アンカー生合成の最初の過程であるが、この反応は GPIGlcNAcT (GPI-GnT) 複合体によって触媒される (21)。本酵素 は小胞体に存在し、反応は細胞質側で行われる。哺乳類では 
Trends in Glycoscience and Glycotechnology Vol.18 No.101 (May 2006) pp.209-230

five proteins(Gpi1p, Gpi2p, Gpi3p, Gpi15p, and Eri1p). Considering amino acid sequences, PIG-A and Gpi3p are deduced as catalytic subunits. Interestingly, Sobering et al., showed that Eri1p and Gpi2p associate with constitutively active(GTP-bound) form of Ras2, and that the enzymatic activity of GPI-GnT is suppressed in the presence of the active Ras2(69). In contrast, Murakami et al., showed that PIG-Y, putative ortholog of Eri1p in mammals, does not associate with H-ras, K-ras, R-ras, and Rap1, and that GPI-GnT activity is unaffected by excess expression of the Ras proteins(21). This discrepancy was explained to be the difference in necessity of GPI-anchor proteins, because in yeast, GPIanchor proteins are essential for maintaining rigid cell wall, and their biosynthesis should be regulated strictly according to the growth of cells.

Gao et al., reported that $\beta 1,4-G l c N A c T$, which acts on GlcNAc-PP-Dol, consists of at least two proteins, Alg13p and Alg14p(70). From the amino acid sequences, Alg13p is likely to bear catalytic activity, but curiously, this protein contains no transmembrane region. In contrast, $\mathrm{Alg} 14 \mathrm{p}$ contains three potential transmembrane regions, but doesn't have any consensus motif for GTs. They showed that suppression of expression level of Alg14p causes relocation of Alg13p from the ER membrane to cytosol, suggesting that Alg14p anchors soluble Alg13p on the cytosolic surface of the ER. When searching for new GTs in various databases, one could encounter GT-like proteins having no transmembrane region. In these cases, it should be primarily considered whether the sequence data are devoid of $N$-terminal sequences probably including transmembrane regions, otherwise whether those soluble proteins associate with certain anchor components.

Mannan biosynthesis in S. cerevisiae starts in the Golgi apparatus from the addition of one $\alpha 1$,6-Man to the $\alpha 1,3$ Man residue $\left[\rightarrow 2 \mathrm{Man} \alpha 1 \rightarrow 3\left(\operatorname{Man}_{4} \rightarrow 6\right) \mathrm{Man} \beta 1 \rightarrow 4\right]$ in $\mathrm{Man}_{8} \cdot$ GlcNAc $_{2}$ glycans via $\alpha 1,6-\mathrm{ManT}(\mathrm{Och} 1 \mathrm{p})(71)$. Next, mannan polymerase I(M-Pol I) adds $\sim 10 \alpha 1$,6-Man residues linearly to the $\alpha 1,6-$ Man introduced by Och1p, and thereafter mannan polymerase II(M-Pol II) synthesizes polymers of 50 100 $\alpha 1,6-$ Man residues. Finally, $\alpha 1,2-$ Man and $\alpha 1,3-$ Man residues are attached to the linear $\alpha 1,6-$ Man polymers as side chains. In contrast, in the cases of proteins destined not to bear mannan, $\alpha 1$,6-Man elongation doesn't occur because of the alternative addition of $\alpha 1,2-\mathrm{Man}$ and $\alpha 1,3-\mathrm{Man}$ residues to the $\alpha 1,6-$ Man introduced by Och1p. Jungmann et al., showed that M-Pol II is a large complex with molecular weight, $>1,000 \mathrm{kDa}$, and composed of five kinds of proteins(Mnn9p, Mnn10p, Mnn11p, Anp1p, and Hoc1p)(Summarized in 20). All the five proteins contain DXD sequences as a GT motif, and among them, Mnn10p and Mnn11p may mainly contribute to the $\alpha 1,6-\mathrm{ManT}$ activity of M-Pol II. Elongation of $\alpha 1,6-$ Man polymers is terminated by capping of $\alpha 1,2-\mathrm{Man}$
GPI-GnT は少なくとも 7 種類のタンパク質 (DPM2、GPI1、PIG$\mathrm{A} 、-\mathrm{C} 、-\mathrm{H} 、-\mathrm{P} 、-\mathrm{Y})$ から成り、酵母では少なくとも5 種類のタン パク質 (Gpilp、Gpi2p、Gpi3p、Gpi15p、Erilp)功成る。アミノ 酸配列の分析から触媒サブユニットはそれぞれ PIG-A および Gpi3pであると推測されている。興味梁いことに Sobering ら は酵母の GPI-GnT のサブユニット Eri1p および Gpi2p が活性 型 (GTP 結合型) Ras2 と会合すること、そして活性型 Ras2 存 在下で GPI-GnT 活性が顕著に抑制されることを示した(69)。 一方哺乳類における Eri1p のオーソログは hydropathy plot か ら PIG-Yであると考えられているが、Murakami らは PIG-Y が H-ras、K-ras、R-ras や Rap1 とは会合せず、またRas の過剩発現 によっても GPI-GnT 活性は減少しないことを示した(21)。こ の違いは生物種によって GPIアンカータンパク質の必要性の 度合いが異なることに基づいていると考えられている。すな わち酵母では GPI アンカータンパク質は細胞壁を構成する必 要かつ重要な成分であり、細胞の生育過程において厳密な生 合成制御が必要とされるためと考えられる。

Gao らは GlcNAc-PP-Dol に作用する $\beta 1,4-G l c N A c T$ が少な くとも $\mathrm{Alg} 13 \mathrm{p} 、 \mathrm{Alg} 14 \mathrm{p}$ の二つのタンパク質の複合体であるこ とを示した(70)。アミノ酸配列から $\mathrm{Alg} 13 \mathrm{p}$ が触媒活性を持つ と考えられるが、不思議なことに $\mathrm{Alg} 13 \mathrm{p}$ は膜貫通領域を持 たない。一方 $\mathrm{Alg} 14 \mathrm{p}$ は膜貫通領域を 3 ケ所持っているが触媒 作用を示す配列を持っていない。Alg14p の発現を抑制すると Alg13p が細胞質へ移行することから、膜タンパク質 Alg14p は 細胞質タンパク質 Alg13p を小胞体膜(細胞質側)上につなぎ止 める役割を担っていると考えられた。我々はデータベースを 検索している際時折膜貫通領域を持たない糖転移酵素らしき タンパク質に出くわすことがあるが、これらのデータ配列の 5 側が欠けている(膜貫通領域の部分のデータが欠けている) 可能性以外に、何らかの膜タンパク質と会合して複合体を形 成し機能している可能性をも考える必要があろう。

S. cerevisiae のマンナンの生合成は、ゴルジ体に扔いて $\mathrm{Man}_{8} \mathrm{GlcNAc}_{2}$ 糖鎖の $\alpha 1,3 \mathrm{Man}$ 残基 $\left[\rightarrow 2 \mathrm{Man} \alpha 1 \rightarrow 3\left(\mathrm{Man}_{4} \rightarrow 6\right)\right.$ $\operatorname{Man} \beta 1 \rightarrow 4] へ \alpha 1,6-M a n T$ (Och1p) (71) がマンノースを一残基 付加することで始まる。続いてこの Man 残基にマンナンポリ メラーゼ I（M-Pol I）の作用で十個前後の $\alpha 1,6-\mathrm{Man}$ が直鎖状に 付加し、さらにマンナンポリメラーゼ II（M-Pol II）の作用で、 $50 \sim 100$ 残基の $\alpha 1,6$ 結合ポリマンノース鎖が伸長される。そ の後直鎖ポリマンノースへ側鎖として $\alpha 1,2-M a n 、 \alpha 1,3-M a n$ が 付加し、マンナンが完成する。一方マンナンを持たざる運命 のタンパク質では Och1pによる $\alpha 1,6-\mathrm{Man}$ 付加の後、 $\alpha 1,2-\mathrm{Man}$ および $\alpha 1,3-M a n$ が付加し、マンナンの伸長は起こらない。 Jungmann らは M-Pol II が分子量 1,000 kDa 以上の巨大複合体 であり、五種のタンパク質 (Mnn9p, Mnn10p, Mnn11p, Anp1p, Hoc1p)から構成されていることを示した(20に要約)。この五 種のタンパク質はすべて DXD 配列を持ち、糖転移酵素である 可能性を有しており、特に Mnn10p, Mnn11p が M-Pol II 複合体 の $\alpha 1,6-\mathrm{ManT}$ 活性に主に寄与しているらしい。マンナンの伸 長は $\alpha 1,2-$ Man が非還元末端に付加することで停止するが、彼 
residue. They speculated that other subunit(s) of M-Pol II is involved in the $\alpha 1,2$-mannosylation. It's interesting that both elongation and termination are performed by single complex. On the other hand, Stolz and Munro showed that M-Pol I is a heterodimer of Mnn9p and Van1p. They also suggested that Mnn9p adds the second $\alpha 1,6-$ Man to the $\alpha 1,6-$ Man residue introduced by Och $1 \mathrm{p}$, and that thereafter Van1p polymerizes $\sim 10 \alpha 1,6-$ Man residues(72). Surprisingly, Mnn9p exhibits both $\alpha 1,2-$ and $\alpha 1,6-M a n T$ activities in vitro. They speculated that Mnn9p can distinguish non-mannan proteins in some way and act as $\alpha 1,2-\mathrm{ManT}$ to stop initiation of $\alpha 1,6-\mathrm{Man}$ polymer synthesis. Although it should be confirmed whether single enzyme can introduce two distinct linkages, the possibility is very attractive that $\mathrm{Mnn} 9 \mathrm{p}$ can recognize which substrate glycoproteins are destined to have mannan, and can introduce different linkages of Man, perhaps by certain conformational change.

Girrbach and Strahl revealed complex formation among the members of yeast protein $O$-ManT(Pmt) family(73). From amino acid sequence similarity, Pmt family is divided into Pmt1 subfamily(Pmt1p and Pmt5p), Pmt2 subfamily(Pmt2p, $3 p$, and $6 p)$, and Pmt4 subfamily(Pmt4p). They showed that Pmt1p and Pmt5p make complexes with Pmt2p and Pmt3p, respectively, and that Pmt $4 p$ forms a homooligomer. Further, as minor constructs, Pmt1p and Pmt5p associate with Pmt3p and Pmt $2 p$, respectively, indicating that hetero-complexes can be formed only between Pmt1 subfamily members and Pmt2 subfamily members. In wild-type yeast, protein $O$-ManT activity seems to be mainly attributed to Pmt1p-Pmt2p complex, and Pmt3p-Pmt5p complex serves complementally. However, precise substrate specificities of these complexes should be clarified, because of the possibility that these complexes could act on distinct Ser/Thr residues in clustered $O$-mannosylation sites.

$O$-GlcNAcT(OGT) introduces GlcNAc to Ser/Thr residues of various cytosolic and nuclear proteins. Hart's laboratory has purified OGT and identified it as 2:1 heterocomplex of $110 \mathrm{kDa}$ and $78 \mathrm{kDa}(74)$, and further showed that recombinant trimer of $110 \mathrm{kDa}$ alone has enough enzymatic activity(75). OGT bears $\sim 11$ TPR sequences(tetratricopept ide repeats) in the $\mathrm{N}$-terminal half and a catalytic region in the C-terminal. Kreppel and Hart showed that a construct lacking three TPRs from the $\mathrm{N}$-terminal is enzymatically active and can form a trimer, while a construct lacking six TPRs is similarly active but fails to form any complex $(\Delta 6$ monomer)(75). TPR is present in various proteins and involved in protein-protein interaction. In the case of OGT, TPR is required for the trimer formation. Next, they evaluated the kinetic parameters of trimer and $\Delta 6$ monomer, and found that the reaction velocity of trimer is greater in a relatively high concentration of UDP-GlcNAc than that of
らは M-Pol II の他のサブユニットがこの $\alpha 1,2$ 付加に関わって いる可能性を示唆している。すなわち伸長と停止を一複合体 で行ない得る可能性を示唆しており興味深い。また Stolz お よびMunroによると M-Pol I は Mnn9p と Van1pのへテロダ イマーであり、Och1pによる $\alpha 1,6-\mathrm{Man}$ 付加の後、二番目の a1,6-Man の付加に Mnn9p が、その後の約十残基の $\alpha 1,6-$ Man の伸長にVan1p が関与していると示唆されている $(72)$ 。興味 深いことに、彼らは Mnn9p がインビトロで $\alpha 1,2-$ 执よび $\alpha 1,6-$ ManT 活性を持つことを示し、一つの可能性として扔そらくマ ンナンを持たないタンパク質に対しては $\mathrm{Mnn} 9 \mathrm{p}$ の働きで $\alpha 1,2-$ Manが入り、 $\alpha 1,6-$ Manオリゴマー鎖の生合成が停止すると推 測している。同一の酵素が $\alpha 1,2 、 \alpha 1,6$ の異なる結合位置を導 入できるかどうかさらに明らかにされなければならないが、 基質タンパク質がマンナンを付加すべき標的か否かを Mnn9p が識別し、 $\alpha$-Manの結合位置の使い分けを行っている可能性 があり、大変興味深い。

Girrbach 抒よびStrah1 らは酵母のタンパク質の $O$ - マンノ シル化に預かるプロテイン $O$-ManT $(\mathrm{Pmt})$ ファミリーの複合体 形成について調べている(73)。Pmtファミリーはそのアミノ 酸配列の類似性から Pmt1 サブファミリー（Pmt1p と Pmt5p）、 Pmt2 サブファミリー（Pmt2p、3p および 6p)、Pmt4 サブファミ リー (Pmt4p)に分類される。彼らはPmt1pは Pmt2p と、Pmt3p はPmt5p とそれぞれ会合体を形成し、Pmt4pはホモオリゴマー を形成することを示した。またマイナー成分として Pmt1p と Pmt3p、そして Pmt 2p と Pmt5p の会合体の存在も示された。す なわち Pmt1 掠よび Pmt2 サブファミリー間でのへテロ複合体 の形成のみが見られた。通常では Pmt1p-Pmt2p が主要な活性 に預かり、Pmt3p-Pmt5p は補助的であるらしい。ただ $O$-マン ノシル化はペプチド上にクラスターとして付加されやすく、 これら複合体が $O$ - マンノシル化の順序などで機能的に使い分 けされている可能性も否定できない。詳しい特異性の解析が 待たれる。

$O-\mathrm{GlcNAc}$ 転移酵素 (OGT) は特定の細胞質および核タンパ ク質の Ser/Thr 残基に $O$-GlcNAc を付加する酵素である。Hart のグループによって OGT の精製品は $110 \mathrm{kDa}$ と $78 \mathrm{kDa}$ の 2:1 ヘテロ複合体であることが示されたが(74)、リコンビナン ト体では $110 \mathrm{kDa}$ のトリマーで十分な酵素活性を示すことが 判った(75)。OGT は N 端側に34アミノ酸からなる TPR 配列 (tetratricopeptide repeats)の繰り返しを 11 個有しており C 端側 に触媒領域を持っている。Kreppel および Hart は TPRのうち $\mathrm{N}$ 端から 3 個までを削除した変異体はトリマー形成能を保持 しているが、6個まで削除するとトリマー形成能を失い、モノ マーになることを示した $(\Delta 6$ モノマー) $(75)$ 。ただし両変異体 とも酵素活性は保持されている。TPR 配列は様々なタンパク 質に存在し、タンパク質間相互作用に関わるエレメントであ る。OGTに扔いて TPR はトリマー形成に重要な役割を果た していることが示された。次に彼らは野生型トリマーと $\Delta 6$ モ ノマーの酵素学的解析を行い、比較的高濃度の UDP-GlcNAc に対する反応速度はトリマーの方が大きいことを明らかにし 
$\Delta 6$ monomer(75). From these results, they speculated that expression levels of $O$-GlcNAc in substrate proteins could be affected by UDP-GlcNAc concentration or complex formation. Recently, OGT-associated proteins have been found, including mSin3A(76), GRIF-1 and its homolog OIP106(10,77), Ser/Thr phosphatases(PP1 $\beta$ and PP1 $\gamma)(78)$, and ataxin-10(11). Among them, at least mSin3A, GRIF-1, and OIP106 bind to the TPR region of OGT. Additionally, using two-hybrid methods, Iyer et al., have found many candidates which can interact with OGT, indicating the occurrence of novel OGT-associated proteins(10). We don't address all the studies of OGT here, but these are medically valuable because complex formation of OGT with other proteins may be related to molecular mechanisms of Alzheimer's disease and diabetes.

\section{G. Molecular Mechanisms Underlying Complex Formation}

As GT complexes individually play distinct biological roles, molecular mechanisms underlying complex formation are diverse, too. First I will address the studies that catalytic domains are critical for the association. Several reports in Table I showed that a soluble form of GTs prepared from serum or cultured media can associate as dimers or oligomers, suggesting the involvement of catalytic regions and/or stem regions in complex formation. Opat et al., showed that a recombinant soluble form of $\beta 1,2-$ GlcNAcT-I(GnT-I) associates with high molecular weight fractions, similarly indicating the involvement of the catalytic and/or stem regions(79). Mougous et al., analyzed the crystal structure of a SulT acting on trehalose, and showed that the SulT forms dimer which arranges each trehalose-binding site in close proximity $(80)$.

The existence of disulfide bonds in catalytic regions has been clearly shown in the case of $\mathrm{GM}_{2}$ synthase. Li et al., analyzed peptide fragments which were produced by several kinds of site-directed cleavages of $\mathrm{GM}_{2}$ synthase dimer, and determined the positions of disulfide bonds(81). Consequently, there exist four disulfide bonds between two subunits; the $\mathrm{Cys}^{80}$ and $\mathrm{Cys}^{82}$ of one subunit are linked with the $\mathrm{Cys}^{412}$ and $\mathrm{Cys}^{529}$ of the other. Therefore the dimer structure of this enzyme should be more stable than that of other GTs described below, which are bridged by disulfide bond(s) in the stem and/ or transmembrane regions. The complex formation of $\mathrm{GM}_{2}$ synthase should be essential for the enzymatic activity.

Colley's laboratory showed that there exist two types(STcys and STtyr) of $\alpha 2,6$-SiaT-I, which bear Cys and Tyr at position 123, respectively, and that the former tends to form insoluble oligomers more than the latter(82). Since disulfide linkage at $\mathrm{Cys}^{123}$ is not concerned with the oligomer formation, difference in the conformation of the catalytic domains is likely to influence their ability to form insoluble oligomers.

UDP-GlcATs(UGT) serving intracellular detoxication
た(75)。この結果は細胞内の UDP-GlcNAc 濃度および OGT の 会合状況によって細胞内タンパク質の $O$-GlcNAc 化のレベル が変化する可能性を示唆している。最近、OGT と会合する夕 ンパク質が見つかってきた。例えば $\mathrm{mSin} 3 \mathrm{~A}$ （76）、GRIF-1 と そのホモログである OIP106(10,77)、Ser/Thr ホスファターゼ (PP1ß、PP1 $\gamma)$ (78)、ataxin-10(11)などがある。これらのうち mSin3A、GRIF-1、OIP106 は OGT の TPR 領域と結合するこ とが明らかになっている。またIyer らは two-hybrid 法により OGT と結合するクローンを多数見い出しており、OGT と結 合するタンパク質の種類は今後さらに増えると思われる(10)。 OGT の研究領域は広いためここでは詳しく触れないが、これ らの複合体形成はアルッハイマー病や糖尿病との関連性が示 唆されており、医学的見地からも大变興味深い。

\section{G. 複合体形成の分子機構}

複合体がそれぞれのケースで異なった役割を示すように、 会合の分子機構も多様である。まずは触媒領域が会合に関わ る例について述べたい。表Iに示したいくつかの例は可溶性 酵素がダイマーもしくはオリゴマーとして存在することを示 しており、複合体形成に触媒領域やステム領域が重要である ことを示唆している。Opat らは可溶型 GnT-Iを発現させた際、 これが高分子画分に会合していることを示し、その触媒領域 もしくはステム領域が会合体形成に重要であることを示した （79）。またMougous らはトレハロースの硫酸化に関わる硫 酸転移酵素の $\mathrm{X}$ 線結晶解析を行い、二つの触媒領域がトレハ ロース結合サイトを近接させる形で結合していることを示し た(80)。

触媒領域に扔けるジスルフィド結合の存在は $\mathrm{GM}_{2}$ シン ターゼの例で明快に示されている。 Li らは $\mathrm{GM}_{2}$ シンターゼ のダイマーに対し、種々の限定分解を施してその産物の分析 を行い、ジスルフィド結合の位置を同定した $(81)$ 。その結果、 一方のサブユニットの $\mathrm{Cys}^{80} 、 \mathrm{Cys}^{82}$ は他方のサブユニットの $\mathrm{Cys}^{412} 、 \mathrm{Cys}^{529}$ とジスルフィド結合を形成し、合計 4 本のジス ルフィド結合がサブユニット間に存在していることを示した。 この䤏素は後で述べるステム領域や膜貫通領域の Cys のジス ルフィド架橋を持つ酵素群と比べより強固で安定なダイマー 構造をとっており、酵素活性にダイマー構造が必須であるこ とを示唆している。

Colley のグループは $\alpha 2,6$-SiaT I には触媒領域内の 123 番 目のアミノ酸残基が異なる二つの型 (STcys と STtyr)が存在す ることを明らかにしているが、前者の方が後者より不溶性才 リゴマーを形成しやすいことを示した $(82)$ 。なお、この形成 には $\mathrm{Cys}^{123}$ 同士のジスルフィド結合は関与しないことから、 触媒領域のコンホメーションの違いが不溶性オリゴマー形成 能に関わっていると考えられる。

細胞内の解毒反応に関与する UDP-GIcAT (UGT) は小胞 体に局在する I 型膜タンパク質であり、N 端側から触媒領域 (小胞体内腔側)、膜貫通領域、短い細胞質領域からなる。触 
are ER-resident, type I membrane proteins, and are made up of the catalytic domain in the lumenal side of the ER, transmembrane region, and short cytoplasmic tail. The catalytic domains are divided into two regions; highly conserved(UGT2 family) or common(UGT1 family) $\mathrm{C}$-terminal region and less conserved $\mathrm{N}$-terminal region. It has been believed that the former recognizes UDP-GlcA, while the latter recognizes acceptor substrates. Meech and Mackenzie showed that the $\mathrm{N}$-terminal region of UGT2B1 is essential for the dimer formation(18). Similarly, Ghosh et al., showed the importance of the $\mathrm{N}$-terminal region for dimerization of UGT1A1(17). UGT1A1 is a cause gene for Crigler-Najjar syndrome which exhibits complete or partial deficiency in hepatic glucuronidation, resulting in hyperbilirubinemia. It has been shown that mutant UGT1A1 has a dominant negative effect(14,17).

In some cases, Cys residue(s) in transmembrane regions is critical to forming dimers. Yamaguchi and Fukuda showed that both $\mathrm{Cys}^{29}$ and $\mathrm{His}^{32}$ residues in the transmembrane region of $\beta 4 \mathrm{Gal}-\mathrm{TI}$ are required for the dimer formation, because the point mutant at the two residues failed to form a dimer(64). Aoki et al., showed that the two residues are important for the Golgi retention of $\beta 4 \mathrm{Gal}-\mathrm{TI}(83)$. They noted that if the transmembrane domain forms $\alpha$-helix structure, $\mathrm{Cys}^{29}$ and $\mathrm{His}^{32}$ are likely to be located on one side, so that $\beta 4 \mathrm{Gal}$-TI forms a dimer by disulfide linkage and hydrophilic interaction of these residues. Besides GTs, it has been shown that the first transmembrane domain of $\mathrm{M}$ glycoprotein of avian coronavirus bears at least four hydrophilic amino acid residues $\left(\mathrm{Asn}^{465}, \mathrm{Thr}^{469}, \mathrm{Thr}^{476}\right.$, and $\mathrm{Gln}^{480}$ ) responsible for the Golgi retention of $\mathrm{M}$ glycoprotein $(84,85)$. Among them, at least $\mathrm{Gln}^{480}$ was shown to be involved in the oligomer formation of $\mathrm{M}$ glycoprotein. If the transmembrane domain forms $\alpha$-helix structure, the four residues seem to be clustered on one side. Considering these results and the fact that many GTs bear Cys residue(s)(described later) and hydrophilic residue(s) in the transmembrane domains, it should be studied further whether these residues mediate oligomer formation of GTs.

As described above, STtyr, possesses lower ability to form insoluble oligomers, but at least it can form a dimer. Qian et al., showed the requirement of transmembrane Cys residue for dimer formation of STtyr(86). With regard to $\alpha 1,3-$ fucosyltransferase-VI(FUT6), Borsig et al., showed that the full length, membrane-bound form can dimerize via disulfide bond(s), while the soluble form behaves as a monomer(87). This indicated that FUT6 can form a dimer via Cys residue(s) present in the cytoplasmic tail and/or the transmembrane region. In addition, many GTs bear Cys residue(s) in the transmembrane and/or cytoplasmic regions. Table III shows the presence of Cys residues in these regions of various glycosyl/sulfotransferases. Among 47 transferases surveyed,
媒領域はさらに相同性の極めて高い(UGT2 群)もしくは共通 の (UGT1 群) C 端側領域とやや相同性の低い $\mathrm{N}$ 端側領域に分 けられる。前者は UDP-GlcA の認識に、後者はアクセプター 基質の認識に関わると考えられている。Meech および Mackenzie はUGT2B1 のダイマー形成に関わる領域を調べ、アクセ プター認識に関わるとされる N 端側領域が重要であることを 示した(18)。またGhosh らも同様に UGT1A1 のダイマー形成 にN 端側領域が関与していることを明らかにした(17)。なお UGT1A1 はグルクロン酸抱合欠如のため高ビリルビン血症を 呈する遺伝病であるクリグラー - ナジャー (Crigler-Najjar) 症 候群の原因遺伝子であり、変異型 UGT1A1 はドミナントネガ ティブ効果を示すことが知られている $(14 、 17) 。$

一方膜貫通領域内の Cys 残基がダイマー形成に重要であ ることが報告されている。Yamaguchi および Fukuda は $\beta 4 \mathrm{Gal}-$ TI のダイマー形成に関わるアミノ酸残基について調べ、膜貫 通領域内の $\mathrm{Cys}^{29}$ および $\mathrm{His}^{32}$ 残基の变異型がダイマーを形成 しないことから、両残基がダイマー形成に重要であることを 示した(64)。またAoki らはこの二つの残基は同時に $\beta 4 \mathrm{Gal}$ TI のゴルジ体局在に重要であることを示している(83)。彼ら

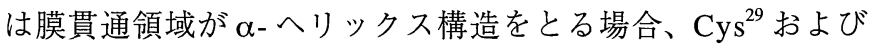
$\mathrm{His}^{32}$ 残基が同じ側面に向く可能性を指摘しており、膜貫通領 域内の親水性残基同士が会合することにより(ジスルフィド結 合を含めて)、ダイマーが形成されることが推測される。な お、糖転移酵素ではないが、avian coronavirus の M glycoprotein の第一膜貫通領域に存在する少なくとも 4 つの親水性アミノ 酸 $\left(\mathrm{Asn}^{465} 、 \mathrm{Thr}^{469} 、 \mathrm{Thr}^{476} 、 \mathrm{Gln}^{480}\right)$ がゴルジ局在に重要であり、こ の領域が $\alpha$ ヘリックス構造をとる場合、同一側面にこれらの 残基が並ぶことが指摘されている $(84,85)$ 。また少なくとも $\mathrm{Gln}^{480}$ が M glycoprotein のオリゴマー形成に重要であることが 示された。糖転移酵素の膜貫通領域にはしばしばCys 残基や 親水性残基が見られるが、これらの残基と複合体形成の関係 についてはさらに詳しく調べる必要があると思われる。

また、上記の STtyr は不溶性オリゴマーの形成能は低い が、ダイマー形成能を持つ。Qianらは同じく膜貫通領域内 の Cys 残基がSTtyr のダイマー形成に重要であることを示し た(86)。さらに、直接的な証拠は無いが、Borsig らによると

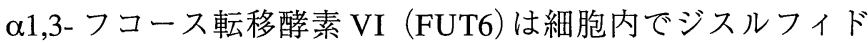
結合によるダイマーを構成し得るが、可溶型を発現させると モノマーのみ生成されることから、細胞質領域もしくは膜貫 通領域の Cys がダイマー形成に関わっていることが考えられ た(87)。ちなみに膜貫通領域や細胞質領域にCys 残基を持つ 糖転移酵素は以外と存在する。表 III にいくつかの糖 / 硫酸転 移酵素群の細胞質領域および膜貫通領域に存在する Cys 残基 
Table III. Occurrence of Cys residues in the cytoplasmic tails (CT) and transmembrane regions (TM) of members of several glyco/ sulfotransferase families (human).

\begin{tabular}{lll}
\hline Glyco/sulfotransferases & CT & TM \\
\hline FUT1 9 & $3,5,6(2)$ & $1(2), 3,4(3), 5,6,9(3)$ \\
$\beta 3 G a 1-T 1 \sim T 6$ & $1,2(2)$ & $1,5(2), 6$ \\
$\beta 4 G a 1-T I \sim T V I I$ & I, II, III, VI, VII & I, II, IV, VII \\
GnT-I V & None & II, III(2), IVb(2) \\
$\beta 3 G n-T 2 \sim T 8$ & $4,6,8(2)$ & $4(2), 5,6,7,8$ \\
ST3Gal-I V & II, IV, V & III \\
GlcNAc6ST1 5, Gal6ST, C6ST1 & 4, Gal6ST, C6ST1 & 1,3 \\
\hline
\end{tabular}

Arabic and roman numerals indicate individual members of these families. Parentheses indicate the presence of two or three Cys residues.

19 enzymes $(40 \%)$ have Cys in the cytoplasmic tails and 24 enzymes $(51 \%)$ in the transmembrane regions. Some enzymes contain a few Cys residues in one region. It should be noted that many Cys residues in cytoplasmic tails are positioned near the boundary to transmembrane regions. Little is known of whether these Cys residues participate in disulfide bonds or not, but some of them might serve complex formation.

Several studies support the involvement of stem regions. Nilsson et al., showed that part of the stem region of $\beta 1,2-G l c N A c T-I(G n T-I)$ is essential for the association with $\alpha$-mannosidase-II, and that especially $\mathrm{Asp}^{77}, \mathrm{Arg}^{83}$, and $\mathrm{Arg}^{85}$ charged residues in the stem region are indispensable(53). Ouzzine et al., showed that $\mathrm{Cys}^{33}$ present in the stem of a $\beta 1,3-G l c A T(G l c A T-I)$ is involved in the dimer formation(88). GlcAT-I acts on the early step of glycosaminoglycan biosynthesis. A mutant enzyme in which $\mathrm{Cys}^{33}$ is converted to Ala, fails to dimerize, and its $\mathrm{Km}$ value is $2 \sim 3$ times greater than that of wild-type dimer. This result indicated the enhancement of the catalytic ability by dimerization. de Graffenried and Bertozzi showed that $\mathrm{Cys}^{39}$ present in the stem of GlcNAc 6-O-SulT-1(GlcNAc6ST-1) is involved in the dimer formation(89). Additionally, there exists one more $\mathrm{Cys}^{12}$ in the transmembrane region of this enzyme, which also contributes to the dimerization. Nagai et al., showed that three heparan sulfate 6-O-SulTs cannot form oligomers when lacking the stem regions(90). Sasai et al., showed that $\beta 1,6-$ GlcNAcT-V(GnT-V) fails to form oligomers when lacking the stem region $\left(\mathrm{Met}^{45}-\mathrm{Ser}^{184}\right)(91)$. This oligomerization seems to be mediated by both a hydrophobic amino acid cluster in the stem region and disulfide linkage(s). Part of the stem region can form $\alpha$-helix structure, which assembles hydrophobic amino acid residues on one side $\left(\mathrm{Leu}^{86}-\mathrm{Val}^{108}\right)$. This hydrophobic cluster could promote the oligomerization. On the other hand, Weinstein et al., showed that a mutated GnT-V, which replaces Leu ${ }^{188}$ with Arg, exhibits similar levels of stability and enzymatic activity with the wild-type enzyme, but it is retained in the ER(92). Since there exists a cluster of several hydrophobic amino acids near $\mathrm{Leu}^{188}\left(\mathrm{Phe}^{184}\right.$ $\mathrm{Leu}^{188}$ ), they noted the possibility that aberrant retention of the mutated GnT-V in the ER is caused by conformational change
数についてまとめた。調べた 47 種の酵素のうち細胞質領域に Cys 残基を持つものは 19 種 (40\%)、膜貫通領域に持つものは 24 種 (51\%)であった。同じ領域にCys を 2 残基以上持つもの も存在する。また細胞質領域に存在するCys 残基の特徽とし て膜結合領域のすぐ近傍に位置する例が多い。これらの Cys 残基の架橋の有無についてはほとんどの例で不明であるが、 何らかのかたちで複合体形成に関与していることが推測され る。

ステム領域の重要性もいくつかの例で示されている。Nilsson らは $\beta 1,2$-GlcNAcT-I（GnT-I）のステム領域の一部が $\alpha$ - マ ンノシダーゼII との複合体形成に必要であることを示した (53)。この領域のうち特に $\mathrm{Asp}^{77} 、 \mathrm{Arg}^{83} 、 \mathrm{Arg}^{85}$ といった電荷 を持つ残基の重要性が示唆された。Ouzzine らはグリコサミノ グリカンの生合成初期に関わる $\beta 1,3-G l c A T$ (GlcAT-I)のダイ マー形成にステム領域の $\mathrm{Cys}^{33}$ が関与していることを示した (88)。興味深いことに $\mathrm{Cys} \rightarrow \mathrm{Ala}$ とした変異型 (モノマー型) は酵素活性を有するが、野生型 (ダイマー)に比べ $\mathrm{Km}$ が $2 \sim 3$ 倍大きくなっており、ダイマー化による触媒機能の増大が示 唆された。また、de Graffenried および Bertozzi は GlcNAc 6-OSulT-1 (GlcNAc6ST-1)のダイマー形成にステム領域の Cys ${ }^{39}$ が 重要であることを示した $(89)$ 。膜貫通領域にも $\mathrm{Cys}^{12}$ が存在す るがこれもダイマー化に寄与していた。またNagai らは三種 のヘパラン硫酸 6-O-SulT はいずれもオリゴマー形成能を持つ が、ステム領域の削除により形成能を失うことを示した $(90)$ 。 Sasai らは $\beta 1,6-G l c N A c T-V （ G n T-V)$ のリゴマー化機構につ いて調べ、 $\mathrm{Met}^{45}-\mathrm{Ser}^{184}$ のステム領域を欠損させるとオリゴマー を形成しないことを示した(91)。このオリゴマー化にはジス ルフィド結合に加えステム領域に存在する疎水性アミノ酸が 関与するらしい。ステム領域の一部は $\alpha$-ヘリックス形成能 を有するが、ある側面に疎水性アミノ酸が集中することから $\left(\mathrm{Leu}^{86}-\mathrm{Val}^{108}\right)$ 、疎水性残基のクラスター同士が結合することが 推測された。一方 Weinstein らは 188 番目の Leu がArgに置換 した変異型 GnT-V は野生型と同様の安定性と酵素活性を持つ が、ゴルジ体へ輸送されず ER にとどまることを示した(92)。 この Leu ${ }^{188}$ の近傍には数残基の疎水性アミノ酸がかたまって 存在していることから $\left(\mathrm{Phe}^{184}-\mathrm{Leu}^{188}\right)$ 、彼らはゴルジから ER 
in the hydrophobic region including Leu ${ }^{188}$. This region is distinct from the position of the hydrophobic cluster which Sasai et al., pointed out, and it is expected to assess whether the $\operatorname{Arg}^{188}$-type GnT-V can form oligomers or not.

Pmt4p, a protein $O$-ManT, bears seven transmembrane regions and can form homooligomers as described above. Pmt $4 p$ loses the ability to oligomerize and the enzymatic activity when an Arg residue, present in the boundary between the first ER-lumenal domain and the following second transmembrane region, is converted to $\mathrm{Glu}(73)$. Pmt1p also possesses Arg residue in the same position, and its substitution to Ala results in disrupting the association with Pmt2p and losing the enzymatic activity. These results indicate that complex formation of Pmts is intimately related to the enzymatic activities, and that specific Arg residue proximal to the transmembrane region is important for the biochemical functions.

$\mathrm{Alg} 1 \mathrm{p}$ bears at least four transmembrane regions in the $\mathrm{N}$-terminal side and the following catalytic domain oriented to the cytosolic face of the ER. Gao et al., reported homooligomer formation of $\mathrm{Alg} 1 \mathrm{p}$ as described above, and further showed that the C-terminal 16 amino acids are critical for oligomer formation(16). Since there is no Cys residue in this sequence, certain non-covalent interaction may occur for the association.

Where does the oligomerization of Golgi-resident GTs take place? Various investigators have performed several experiments such as (i) inhibition of the transport of GTs from the ER to the Golgi by the removal of ER-exit signals, the addition of inhibitory reagents, or low-temperature treatment, (ii) pulse-chase experiments, and (iii) the ERretention of GTs forced by fusion with an ER-retained protein at their cytoplasmic tails. From these experiments, GnT-I and mannosidase II(52,53), $\beta 4$ GalNAc-T1 $\left(\mathrm{GM}_{2}\right.$ synthase $)(93)$, ST8Sia-I $\left(\mathrm{GD}_{3}\right.$ synthase)(94), ST6Gal-I(86), and $\beta 3 \mathrm{Gal}-$ TIV and $\beta 4$ GalNAc-T1(55) were shown to form respective oligomers in the ER. In contrast, Sousa et al., suggested that $\alpha 1,3$ FucT-III(FUT3) exists in the Golgi in an equilibrium of monomer and dimer, because of the presence of both forms(95). At present, evidence for this possibility is limited to in vitro biochemical studies, so further investigation will be expected. In addition, Fenteany and Colley suggested that the oligomerization of $\alpha 2,6$-SiaT-I(STcys-type) is the secondary event caused by the high concentration of the enzyme in the Golgi(1).

\section{H. Conclusion}

Recent progress in analytical methods greatly promotes the studies for enzyme complexes. Although complex studies had been dependent on classical purification methods, they became easier and clearer by exploitation of several
への局在性の変化はこの領域のコンホメーション変化に起因 する可能性を指摘している。この領域は Sasai らの指摘した疎 水性クラスターとは異なる領域であり、 $\mathrm{R}^{188}$ 型 GnT-Vがオリ ゴマーを形成しうるか否か興味深い。

プロテイン O-ManT 群 (Pmt) は前述のようにホモ複合体や ヘテロ複合体を形成することが知られている。Pmt $4 \mathrm{p}$ は 7つ の膜貫通領域を持つタンパク質であり、ホモ複合体を形成す るが、 $\mathrm{N}$ 端から二番目の膜貫通領域とその $\mathrm{N}$ 端側の小胞体内 腔側領域の境界に存在する Arg 残基を Gluに置換するとホモ 複合体を形成出来できなくなり、酵素活性を失う(73)。また Pmt1p も同様の位置にArg を持つがこれを Alaに置換すると $\mathrm{Pm} 2 \mathrm{p}$ と会合できなくなり、同様に酵素活性を失う。このこ とはPmtの複合体形成と酵素活性が相関しており、特定の膜 貫通領域近傍のアミノ酸が重要であることを示唆している。

$\mathrm{Alg} 1 \mathrm{p}$ (前述)は少なくとも 4 つの膜貫通領域を $\mathrm{N}$ 端側に 持ち、C 端側に小胞体の細胞質側に表出した触媒領域を有し ている。GaoらはAlg1pの木モ複合体について報告している が、この複合体形成には $\mathrm{C}$ 末端の 16 アミノ酸残基が必要であ ることを示した(16)。ちなみにこの 16 残基中には Cys 残基は 存在しないため、この配列を含む領域の高次構造が複合体形 成に必要であることが考えられる。

ところでゴルジ局在性糖転移酵素のオリゴマー化はどこ で起こるのであろうか?これまでに(i)ER exit シグナルの除 去、薬剤処理、もしくは低温操作による ER からゴルジ体へ の輸送の阻害実験、(ii) パルス - チェイス実験、(iii)ER 局在 タンパク質を融合させたリコンビナント体を作成し、標的酵 素を強制的に ER 局在にする実験などにより、GnT-I とマン ノシダーゼ II (52、53)、ß4GalNAc-T1 $\left(\mathrm{GM}_{2}\right.$ シンターゼ) (93)、 ST8Sia-I (GD シンターゼ) (94)、ST6Gal-I (86)、 $\beta 3 G a l-T I V$ と B4GalNAc-T1（55）はERで木モもしくはへテロ会合体を それぞれ形成することが示唆されている。一方、Sousaらは $\alpha 1,3$ FucT-III（FUT3)について、ジスルフィド結合を介したダ イマーとモノマーが共に存在することから、ゴルジ体におい てダイマーとモノマーが平衡状態で存在することを推測して いる (95)。ただ実験的根拠が in vitro での生化学的解析にとど まっており、更なる証明が期待される。またFenteany および Colley らは STcys のオリゴマー形成はゴルジ体において酵素 タンパク質が濃縮されたときに起こる二次的結果であること を推測している(1)。

\section{H. 終わりに}

複合体の解析には分析技術の進歩によるところが大きい。 当初は酵素の精製に依存していたがやがて種々の夕グが開発 され、解析がより容易で明快なものになった。そして今日で は極微量のタンパク質も質量分析で決定できるようになり、 
tag elements. Lately, very small amounts of proteins or subunits can be identified by mass spectrometry. Analyses of components in enzyme complexes will be performed rapidly. Thereafter two big issues would arise. One is to clarify individual functions of all subunits in complexes; for example, which subunit(s) bear catalytic activities, whether the other subunits activate, inactivate, or stabilize the enzymatic activities, whether biological functions of complexes are modified in the presence of certain effector proteins, and so on. The other is to clarify molecular mechanisms whereby individual subunits recognize each other. For this issue, in vitro reconstitution of complexes and $\mathrm{X}$-ray crystal structure studies will be required. Although studies on the relationship between GT complexes and diseases are limited to genetic ones to date, it will be expected with the progress of studies that GT complexes are associated with certain diseases and targeted for medical application.
複合体の構成員を明らかにする試みは今後急速に為されてい くであろう。そしてその後に二大テーマが待っていると思わ れる。一つは複合体における各構成員の機能をそれぞれ明ら かにすることである。すなわち、反応を行うのはどのサブユ ニットか、また他のサブユニットは複合体を活性化するのか 不活性化するのか、それとも安定化するのか、さらに特定の サブユニットの有無が生理的機能に影響するかどうか、など である。もう一つは複合体を形成する分子機構、つまりどの ような分子的結合様式に基づいて互いに結合すべき相手を識 別するか、を明らかにすることである。これらを調べるため には複合体の再構成実験や立体構造解析などが重要になるで あろう。また複合体形成と疾患との関連性が明らかになった ものは現在のところ遺伝病の範囲に留まっている感があるが、 研究の進展に伴い種々の疾患との関連性が明らかになってく る可能性が考えられる。

\section{References}

1. Fenteany, F.H., and Colley, K.J. (2005) J. Biol. Chem. 280, 5423-5429

2. Bao, M., Booth, J.L., Elmendorf, B.J., and Canfield, W.M. (1996) J. Biol. Chem. 271, 31437-31445

3. Kudo, M., Bao, M., D'Souza, A., Ying, F., Pan, H., Roe, B.A., and Canfield, W.M. (2005) J. Biol. Chem. 280, 36141-36149

4. Kempner, E.S., and Fleischer, S. (1989) Methods Enzymol. 172, 410-439

5. Fleischer, B., McIntyre, J.O., and Kempner, E.S. (1993) Biochemistry 32, 2076-2081

6. Tukey, R.H., and Tephly, T.R. (1981) Arch. Biochem. Biophys. 209, 565-578

7. Peters, W.H.M., Jansen, P.L.M., and Nauta, H. (1984) J. Biol. Chem. 259, 11701-11705

8. Gschaidmeier, H., and Bock, K.W. (1994) Biochem. Pharmacol. 48, 1545-1549

9. Wassler, M.J., Foote, C.I., Gelman, I.H., and Shur, B.D. (2001) J. Cell Sci. 114, 2291-2300

10. Iyer, S.P.N., Akimoto, Y., and Hart, G.W. (2003) J. Biol. Chem. 278, 5399-5409

11. Andrali, S.S., Marz, P., and Ozcan, S. (2005) Biochem. Biophys. Res. Commun. 337, 149-153

12. Yan, A., Wu, E., and Lennarz, W.J. (2005) Proc. Natl. Acad. Sci. USA 102, 7121-7126

13. Nyfeler, B., Michnick, S.W., and Hauri, H.-P. (2005) Proc. Natl. Acad. Sci. USA 102, 6350-6355

14. Koiwai, O., Aono, S., Adachi, Y., Kamisako, T., Yasui, Y., Nishizawa, M., and Sato, H. (1996) Hum. Mol. Genet. 5, 645-647

15. Correia, T., Papayannopoulos, V., Panin, V., Woronoff, P., Jiang, J., Vogt, T.F., and Irvine, K.D. (2003) Proc. Natl. Acad. Sci. USA 100, 6404-6409

16. Gao, X.-D., Nishikawa, A., and Dean, N. (2004) Glycobiology 14, 559-570

17. Ghosh, S.S., Sappal, B.S., Kalpana, G.V., Lee, S.W., Chowdhury, J.R., and Chowdhury, N.R. (2001) J. Biol. Chem. 276, $42108-42115$

18. Meech, R., and Mackenzie, P.I. (1997) J. Biol. Chem. 272, 26913-26917

19. Dan, N., and Lehrman, M.A. (1997) J. Biol. Chem. 272, 14214-14219

20. Jungmann, J., Rayner, J.C., and Munro, S. (1999) J. Biol. Chem. 274, 6579-6585

21. Murakami, Y., Siripanyaphinyo, U., Hong, Y., Tashima, Y., Maeda, Y., and Kinoshita, T. (2005) Mol. Biol. Cell 16, 5236-5246

22. Chavan, M., Yan, A., and Lennarz, W.J. (2005) J. Biol. Chem. 280, 22917-22924

23. Shibatani, T., David, L.L., McCormack, A.L., Frueh, K., and Skach, W.R. (2005) Biochemistry 44, 5982-5992

24. Meunier, L., Usherwood, Y.-K., Chung, K.T., and Hendershot, L.M. (2002) Mol. Biol. Cell 13, 4456-4469

25. McCormick, C., Duncan, G., Goutsos, K.T., and Tufaro, F. (2000) Proc. Natl. Acad. Sci. USA 97, 668-673

26. Senay, C., Lind, T., Muguruma, K., Tone, Y., Kitagawa, H., Sugahara, K., Lidholt, K., Lindahl, U., and Kusche-Gullberg, M. (2000) EMBO Rep. 1, 282-286

27. Kim, B.-T., Kitagawa, H., Tanaka, J., Tamura, J., and Sugahara, K. (2003) J. Biol. Chem. 278, 41618-41623

28. Han, C., Belenkaya, T.Y., Khodoun, M., Tauchi, M., Lin, X., and Lin, X. (2004) Development 131, 1563-1575

29. Izumikawa, T., Egusa, N., Taniguchi, F., Sugahara, K., and Kitagawa, H. (2006) J. Biol. Chem. 281, 1929-1934

30. Kitagawa, H., Izumikawa, T., Uyama, T., and Sugahara, K. (2003) J. Biol. Chem. 278, 23666-23671

31. Bieberich, E., MacKinnon, S., Silva, J., Li, D.D., Tencomnao, T., Irwin, L., Kapitonov, D., and Yu, R.K. (2002) Biochemistry 41, 1147911487

32. Ishii, Y., Miyoshi, A., Watanabe, R., Tsuruda, K., Tsuda, M., Yamaguchi-Nagamatsu, Y., Yoshisue, K., Tanaka, M., Maji, D., Ohgiya, S., and Oguri, K. (2001) Mol. Pharmacol. 60, 1040-1048.

33. Kurkela, M., Hirvonen, J., Kostiainen, R., and Finel, M. (2004) Biochem. Pharmacol. 68, 2443-2450

34. Gentzsch, M., Immervoll, T., and Tanner, W. (1995) FEBS Lett. 377, 128-130

35. Manya, H., Chiba, A., Yoshida, A., Wang, X., Chiba, Y., Jigami, Y., Margolis, R.U., and Endo, T. (2004) Proc. Natl. Acad. Sci. USA $101,500-505$

36. Ichimiya, T., Manya, H., Ohmae, Y., Yoshida, H., Takahashi, K., Ueda, R., Endo, T., and Nishihara, S. (2004) J. Biol. Chem. 279, 42638 $-42647$ 
Trends in Glycoscience and Glycotechnology Vol.18 No.101 (May 2006) pp.209-230

37. Ivatt, R.J. (1981) Proc. Natl. Acad. Sci. USA 78, 4021-4025

38. Seko, A., and Yamashita, K. (2005) Glycobiology 15, 943-951

39. Ishida, H., Togayachi, A., Sakai, T., Iwai, T., Hiruma, T., Sato, T., Okubo, R., Inaba, N., Kudo, T., Gotoh, M., Shoda, J., Tanaka, N., and Narimatsu, H. (2005) FEBS Lett. 579, 71-78

40. Ju, T., and Cummings, R.D. (2002) Proc. Natl. Acad. Sci. USA 99, 16613-16618

41. Ju, T., and Cummings, R.D. (2005) Nature 437, 1252

42. Ashida, H., Hong, Y., Murakami, Y., Shishioh, N., Sugimoto, N., Kim, Y.U., Maeda, Y., and Kinoshita, T. (2005) Mol. Biol. Cell 16, 1439-1448

43. Brodbeck, U., and Ebner, K.E. (1966) J. Biol. Chem. 241, 762-764

44. Brew, K., Vanaman, T.C., and Hill, R.L. (1968) Proc. Natl. Acad. Sci. USA 59, 491-497

45. Ramakrishnan, B., and Qasba, P.K. (2001) J. Mol. Biol. 310, 205-218

46. Takeda, S., Ishii, Y., Iwanaga, M., Mackenzie, P.I., Nagata, K., Yamazoe, Y., Oguri, K., and Yamada, H. (2005) Mol. Pharmacol. 67, 665 $-672$

47. Fremont, J.J., Wang, R.W., and King, C.D. (2005) Mol. Pharmacol. 67, 260-262

48. Miles, E.W., Rhee, S., and Davies, D.R. (1999) J. Biol. Chem. 274, 12193-12196

49. Huang, X., Holden, H.M., and Raushel, F.M. (2001) Annu. Rev. Biochem. 70, 149-180

50. Schwartz, N.B., Roden, L., and Dorfman, A. (1974) Biochem. Biophys. Res. Commun. 56, 717-724

51. Schwartz, N.B. (1975) FEBS Lett. 49, 342-345

52. Nilsson, T., Hoe, M.H., Slusarewicz, P., Rabouille, C., Watson, R., Hunte, F., Watzele, G., Berger, E.G., and Warren, G. (1994) EMBO J. $13,562-574$

53. Nilsson, T., Rabouille, C., Hui, N., Watson, R., and Warren, G. (1996) J. Cell Sci. 109, 1975-1989

54. Giraudo, C.G., Daniotti, J.L., and Maccioni, H.J. (2001) Proc. Natl. Acad. Sci. USA 98, 1625-1630

55. Giraudo, C.G., and Maccioni, H.J.F. (2003) J. Biol. Chem. 278, 40262-40271

56. Hodson, N., Griffiths, G., Cook, N., Pourhossein, M., Gottfridson, E., Lind, T., Lidholt, K., and Roberts, I.S. (2000) J. Biol. Chem. 275, 27311-27315

57. Pinhal, M.A.S., Smith, B., Olson, S., Aikawa, J., Kimata, K., and Esko, J.D. (2001) Proc. Natl. Acad. Sci. USA 98, 12984-12989

58. Sprong, H., Degroote, S., Nilsson, T., Kawakita, M., Ishida, N., van der Sluijs, P., and van Meer, G. (2003) Mol. Biol. Cell 14, 34823493

59. Troy, F.A. (1992) Glycobiology 2, 5-23

60. Steenbergen, S.M., and Vimr, E.R. (2003) J. Biol. Chem. 278, 15349-15359

61. Vann, W.F., Daines, D.A., Murkin, A.S., Tanner, M.E., Chaffin, D.O., Rubens, C.E., Vionnet, J., and Silver, R.P. (2004) J. Bacteriol. 186, 706-712

62. McNulty, C., Thompson, J., Barrett, B., Lord, L., Andersen, C., and Roberts, I.S. (2006) Mol. Microbiol. 59, 907-922

63. Yan, A., Ahmed, E., Yan, Q., and Lennarz, W.J. (2003) J. Biol. Chem. 278, 33078-33087

64. Yamaguchi, N., and Fukuda, M.N. (1995) J. Biol. Chem. 270, 12170-12176

65. Gong, X., Dubois, D.H., Miller, D.J., and Shur, B.D. (1995) Science 269, 1718-1721

66. Dominguez, M., Dejgaard, K., Fullekrug, J., Dahan, S., Fazel, A., Paccaud, J.-P., Thomas, D.Y., Bergeron, J.J.M., and Nilsson, T. (1998) J. Cell Biol. 140, 751-765

67. Giraudo, C.G., and Maccioni, H.J.F. (2003) Mol. Biol. Cell 14, 3753-3766

68. Ma, J., and Colley, K.J. (1996) J. Biol. Chem. 271, 7758-7766

69. Sobering, A.K., Watanabe, R., Romeo, M.J., Yan, B.C., Specht, C.A., Orlean, P., Riezman, H., and Levin, D.E. (2004) Cell 117, 637-648

70. Gao, X.-D., Tachikawa, H., Sato, T., Jigami, Y., and Dean, N. (2005) J. Biol. Chem. 280, 36254-36262

71. Nakayama, K., Nagasu, T., Shimma, Y., Kuromitsu, J., and Jigami, Y. (1992) EMBO J. 11, 2511-2519

72. Stolz, J., and Munro, S. (2002) J. Biol. Chem. 277, 44801-44808

73. Girrbach, V., and Strahl, S. (2003) J. Biol. Chem. 278, 12554-12562

74. Haltiwanger, R.S., Blomberg, M.A., and Hart, G.W. (1992) J. Biol. Chem. 267, 9005-9013

75. Kreppel, L.K., and Hart, G.W.(1999) J. Biol. Chem. 274, 32015-32022

76. Yang, X., Zhang, F., and Kudlow, J.E. (2002) Cell 110, 69-80

77. Iyer, S.P.N., and Hart, G.W. (2003) J. Biol. Chem. 278, 24608-24616

78. Wells, L., Kreppel, L.K., Comer, F.I., Wadzinski, B.E., and Hart, G.W. (2004) J. Biol. Chem. 279, 38466-38470

79. Opat, A.S., Houghton, F., and Gleeson, P.A. (2000) J. Biol. Chem. 275, 11836-11845

80. Mougous, J.D., Petzold, C.J., Senaratne, R.H., Lee, D.H., Akey, D.L., Lin, F.L., Munchel, S.E., Pratt, M.R., Riley, L.W., Leary, J.A., Berger, J.M., and Bertozzi, C.R. (2004) Nat. Struct. Mol. Biol. 11, 721-729

81. Li, J., Yen, T.-Y., Allende, M.L., Joshi, R.K., Cai, J., Pierce, W.M., Jaskiewicz, E., Darling, D.S., Macher, B.A., and Young, W.W.Jr. (2000) J. Biol. Chem. 275, 41476-41486

82. Chen, C., Ma, J., Lazic, A., Backovic, M., and Colley, K.J. (2000) J. Biol. Chem. 275, 13819-13826

83. Aoki, D., Lee, N., Yamaguchi, N., Dubois, C., and Fukuda, M.N. (1992) Proc. Natl. Acad. Sci. USA 89, 4319-4323

84. Machamer, C.E., Grim, M.G., Esquela, A., Chung, S.W., Rolls, M., Ryan, K., and Swift, A.M. (1993) Mol. Biol. Cell 4, 695-704

85. Weisz, O.A., Swift, A.M., and Machamer, C.E. (1993) J. Cell Biol. 122, 1185-1196

86. Qian, R., Chen, C., and Colley, K.J. (2001) J. Biol. Chem. 276, 28641-28649

87. Borsig, L., Katopodis, A.G., Bowen, B.R., and Berger, E.G. (1998) Glycobiology 8, 259-268

88. Ouzzine, M., Gulberti, S., Netter, P., Magdalou, J., and Fournel-Gigleux, S. (2000) J. Biol. Chem. 275, 28254-28260

89. de Graffenried, C.L., and Bertozzi, C.R. (2004) J. Biol. Chem. 279, 40035-40043

90. Nagai, N., Habuchi, H., Esko, J.D., and Kimata, K. (2004) J. Cell Sci. 117, 3331-3341

91. Sasai, K., Ikeda, Y., Tsuda, T., Thara, H., Korekane, H., Shiota, K., and Taniguchi, N. (2001) J. Biol. Chem. 276, 759-765

92. Weinstein, J., Sundaram, S., Wang, X., Delgado, D., Basu, R., and Stanley, P. (1996) J. Biol. Chem. 271, 27462-27469

93. Zhu, G., Jaskiewicz, E., Bassi, R., Darling, D.S., and Young, W.W.Jr. (1997) Glycobiology 7, 987-996 
94. Daniotti, J.L., Martina, J.A., Giraudo, C.G., Zurita, A.R., and Maccioni, H.J. (2000) J. Neurochem. 74, 1711-1720

95. Sousa, V.L., Costa, M.T., Palma, A.S., Enguita, F., and Costa, J. (2001) Biochem. J. 357, 803-810

96. Sarnesto, A., Kohlin, T., Thurin, J., and Blaszczyk-Thurin, M. (1990) J. Biol. Chem. 265, 15067-15075

97. Sarnesto, A., Kohlin, T., Hindsgaul, O., Thurin, J., and Blaszczyk-Thurin, M. (1992) J. Biol. Chem. 267, 2737-2744

98. Faik, A., Bar-Peled, M., DeRocher, A.E., Zeng, W., Perrin, R.M., Wilkerson, C., Raikhel, N.V., and Keegstra, K. (2000) J. Biol. Chem. 275, 15082-15089

99. Eppenberger-Castori, S., Lotscher, H., and Finne, J. (1989) Glycoconj. J. 6, 101-114

100. Haab, C.I., and Keller, F. (2002) Physiol. Plant 114, 361-371

101. Blanken, W.M., and Van den Eijnden, D.H. (1985) J. Biol. Chem. 260, 12927-12934

102. Ju, T., Cummings, R.D., and Canfield, W.M. (2002) J. Biol. Chem. 277, 169-177

103. Schwartz, N.B., and Roden, L. (1975) J. Biol. Chem. 250, 5200-5207

104. Fujita-Yamaguchi, Y., and Yoshida, A. (1981) J. Biol. Chem. 256, 2701-2706

105. Navaratnam, N., Ward, S., Fisher, C., Kuhn, N.J., Keen, J.N., and Findlay, J.B. (1988) Eur. J. Biochem. 171, 623-629

106. Bendiak, B., Ward, L.D., and Simpson, R.J. (1993) Eur. J. Biochem. 216, 405-417

107. Teasdale, R.D., Matheson, F., and Gleeson, P.A. (1994) Glycobiology 4, 917-928

108. Malissard, M., Borsig, L., DiMarco, S., Grutter, M.G., Kragl, U., Wandrey, C., and Berger, E.G. (1996) Eur. J. Biochem. 239, 340-348

109. Schwyzer, M., and Hill, R.L. (1977) J. Biol. Chem. 252, 2338-2345

110. Nagai, M., Dave, V., Kaplan, B.E., and Yoshida, A. (1978) J. Biol. Chem. 253, 377-379

111. Clausen, H., White, T., Takio, K., Titani, K., Stroud, M., Holmes, E., Karkov, J., Thim, L., and Hakomori, S. (1990) J. Biol. Chem. 265, 1139-1145

112. Taniguchi, N., Yokosawa, N., Gasa, S., and Makita, A. (1982) J. Biol. Chem. 257, 10631-10637

113. Kamsteeg, J., van Brederode, J., and van Nigtevecht, G. (1978) Biochem. Genet. 16, 1045-1058

114. Evans, O.P., and O’Reilly, D.R. (1999) J. Gen. Virol. 80, 485-492

115. Chowdhury, J.R., Chowdhury, N.R., Bhargava, M.M., and Arias, I.M. (1979) J. Biol. Chem. 254, 8336-8339

116. Matern, H., Matern, S., and Gerok, W. (1982) J. Biol. Chem. 257, 7422-7429

117. Bruni, S., and Chang, T.M. (1999) Artif. Cells Blood Substit. Immobil. Biotechnol. 27, 343-356

118. Kurkela, M., Garcia-Horsman, J.A., Luukkanen, L., Morsky, S., Taskinen, J., Baumann, M., Kostiainen, R., Hirvonen, J., and Finel, M. (2003) J. Biol. Chem. 278, 3536-3544

119. Terayama, K., Seiki, T., Nakamura, A., Matsumori, K., Ohta, S., Oka, S., Sugita, M., and Kawasaki, T. (1998) J. Biol. Chem. 273, 30295 $-30300$

120. Bendiak, B., and Schachter, H. (1987) J. Biol. Chem. 262, 5775-5783

121. Sadler, J.E., Rearick, J.I., and Hill, R.L. (1979) J. Biol. Chem. 254, 5934-5941

122. Bosshart, H., and Berger, E.G. (1992) Eur. J. Biochem. 208, 341-349

123. Peterbauer, T., and Richter, A. (1998) Plant Physiol. 117, 165-172

124. Kobayashi, M., Habuchi, H., Habuchi, O., Saito, M., and Kimata, K. (1996) J. Biol. Chem. 271, 7645-7653

125. Habuchi, O., Matsui, Y., Kotoya, Y., Aoyama, Y., Yasuda, Y., and Noda, M. (1993) J. Biol. Chem. 268, 21968-21974

126. Sugumaran, G., Katsman, M., and Drake, R.R. (1995) J. Biol. Chem. 270, 22483-22487

127. Shailubhai, K., Huynh, Q.K., Boddupalli, H., Yu, H.H., and Jacob, G.S. (1999) Biochem. Biophys. Res. Commun. 256, $170-176$

128. Huynh, Q.K., Shailubhai, K., Boddupalli. H., Yu, H.H., Broschat, K.O., and Jacob, G.S. (1999) Glycoconj. J. 16, $357-363$

129. Bhakta, S., Bartes, A., Bowman, K.G., Kao, W.-M., Polsky, I., Lee, J.K., Cook, B.N., Bruehl, R.E., Rosen, S.D., Bertozzi, C.R., and Hemmerich, S. (2000) J. Biol. Chem. 275, 40226-40234

130. Ashida, H., Maeda, Y., and Kinoshita, T. (2006) J. Biol. Chem. 281, 896-904

131. Marks, D.L., Wu, K., Paul, P., Kamisaka, Y., Watanabe, R., and Pagano, R.E. (1999) J. Biol. Chem. 274, 451-456

132. Ikushiro, S., Emi, Y., and Iyanagi, T. (1997) Biochemistry 36, 7154-7161

133. Jungmann, J., and Munro, S. (1998) EMBO J. 17, 423-434

Received on February 22, 2006, accepted on March 29, 2006

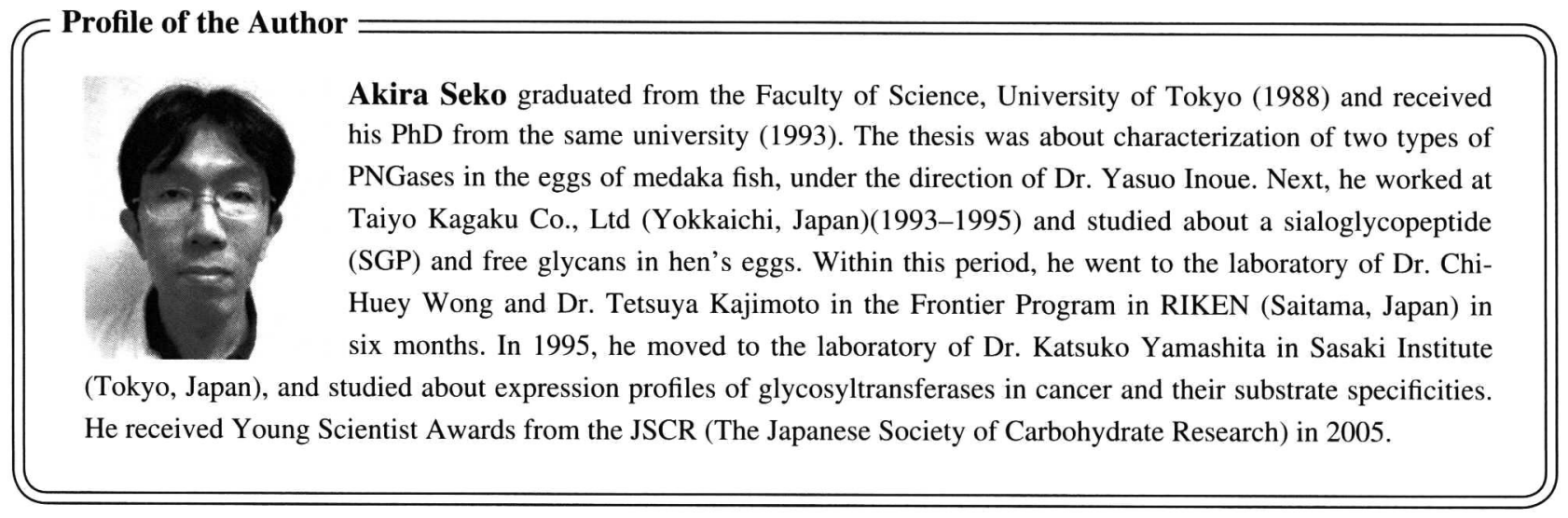

